\title{
Intake and conversion of food in the fish Limanda limanda exposed to different temperatures
}

\author{
T. J. PaNDian \\ Biologische Anstalt Helgoland (Meeresstation); Helgoland, Germany (FRG) \\ and \\ Zoology Department, Bangalore University; Bangalore, India
}

\begin{abstract}
Abstraet
In the flat fish Limanda limanda L., feeding rate and conversion efficiency were studied as functions of body weight, sex, temperature and food quality. When offered herring meat at $13^{\circ} \mathrm{C}$ (series I), females (live weights 1 to $150 \mathrm{~g}$ ) consume more food than males; the magnitude of this difference is body weight-dependent. With increasing weight, both females and males consume less food per unit body weight per day. Variations in daily ration are considerable; the range of deviation from mean feeding rate is about $60 \%$ for males and $40 \%$ for females. The range of deviation does not vary significantly among females and males of different body weights. At the same temperature level $\left(13^{\circ} \mathrm{C}\right.$; series II), females consume almost the same, or even less, cod meat than males. Among individuals of series I and. II, there is a little difference in the feeding rate; however, herring-fed individuals obtain about 2 times more energy than cod-fed individuals. Each gram wet weight of herring meat yields 2001 , each gram cod meat 1137 , calories. Small individuals completely cease to feed at $3^{\circ} \mathrm{C}$; they feed little at $8^{\circ} \mathrm{C}$. Larger females consume maximum amounts at $8^{\circ} \mathrm{C}$. Small individuals consume maximum amounts at higher temperatures. Thus, with increasing body weight (age), the temperature for maximum feeding shifts downwards. Feeding with cod or herring meat results in considerable changes in composition and calorific content of $L$. Limanda. The magnitude of these changes depends both on temperature and food quality. Food conversion efficiency values of herring-fed individuals are about $1 / 2$ times higher than of cod-fed individuals. In series I and II, females are more efficient converters than males. In individuals weighing more than $50 \mathrm{~g}$, conversion efficiency decreases in the order: $8^{\circ}, 13^{\circ}, 18^{\circ} \mathrm{C}$; in smaller individuals this order is $13^{\circ}, 18^{\circ}, 8^{\circ} \mathrm{C}$. Conversion rate is about 2 to 5 times faster in individuals fed herring meat than those receiving cod meat. Conversion rate decreases in the order $13^{\circ}$, $8^{\circ}, 18^{\circ} \mathrm{C}$ in males, and in the order $18^{\circ}, 13^{\circ}, 8^{\circ} \mathrm{C}$ in females; females of more than $80 \mathrm{~g}$ are exceptional in that they reach the maximum at $8^{\circ} \mathrm{C}$. From the data on food intake and food conversion, the biologically useful energy available for metabolism has been caleulated for each test individual kept at $13^{\circ}$ and $18^{\circ} \mathrm{C}$. At these temperature levels, the weight exponents are about 0.6 ; the ' $a$ ' value or metabolic level for the $18^{\circ} \mathrm{C}$ series is about 2 times higher than that at $13^{\circ} \mathrm{C}$. Thus, temperature affects metabolic rate but not the exponential value. The exponential value for the body weight-metabolism relation at $13^{\circ} \mathrm{C}$ is for dab fed herring meat 0.9 ; the ' $a$ ' value amounts to about half that for dab fed cod meat. Food quality, unlike temperature, alters not only the exponential value but also metabolic rate.
\end{abstract}

\section{Introduction}

Supply of energy is imperative for the normal course of life processes; energy enters the animal in the form of food. The food is subjected to a series of physical and chemical changes. Changes through which energy becomes dissipated are collectively called catabolism; changes which lead to deposition in the organism are known as anabolism. These 2 processes occur simultaneously, and are together spoken as metabolism in a broad sense. Energy is released or dissipated through oxidation; biological oxidation implies transfer of a pair of electrons to an atom of oxygen and, hence, oxygen consumption has been regarded as a measure of metabolism. There exists an enormous literature on metabolism of fishes as studied by oxygen consumption (FrY, 1947, 1957; WINBERG, 1956; Beamish and Dickie, 1966).

KINNE (1960) regarded "conversion of food into body substance and into biologically useful energy" as an additional, in many cases more suitable and more sensitive, parameter for assessing rates and efficiencies of metabolic processes. This view of KINNE has recently received. support from Parohermo and Dickre $(1966 a, b)$ who summarized the available information on food conversion in fishes. Feeding-rate and conversion efficiency estimates are considered better parameters of metabolic rates for the following reasons:

(1) The less restricted maintenance conditions during feeding experiments represent better analogies to natural conditions than do the restricted test conditions during determinations of oxygen consumption. (2) Repeated observations on one and the same individual over long periods of time provide data for detailed studies on the contribution of individual versus environmental variations to average metabolic rates. Due to technical difficulties, appropriate data (such as those by SмIтH, 1935) have rarely been obtained from direct respiration studies. (3) Conversion 
studies allow the direct measurement of the effects of quantitative and qualitative aspects of feeding on metabolism; this is essential for an understanding of the production process (see also Parohmrmo and DIOKTE, 1966a).

Previous workers like IVuEv $(1939,1945)$ and GERKING $(1952,1954)$ have shown an indirect relation of body weight (age) to conversion efficiency in the fishes studied by them. This relationship is altered to a greater or lesser extent through environmental factors; of these temperature is the most important one, particularly in thermo-conformers of temperate waters. The pioneering work of KINNE $(1960,1962)$ presents extensive information on temperature relations with regard to food intake, food conversion and growth in the euryplastic fish Cyprinodon macularius. There exist only a few papers (DAWEs, 1930-31; HatTANAKA et al., 1956a, b, 1957; MExzEx, 1960) which are concerned with temperature effects on food intake and food conversion in marine fishes. The paucity of information on food requirements of marine fishes is primarily due to the difficulties encountered in maintaining marine fishes under laboratory conditions. DAWES and HATANAKA and co-workers estimated the food conversion efficiency of flat fishes kept at ambient temporatures, while MENzEx carried out 3 sets of experiments on food conversion efficiency of the Bermuda reef fish $\mathbb{E}_{p i}$ nephelus guttatus maintained at 3 different constant temperature levels. The present paper reports on feeding rate and conversion efficiency of the dab Limanda limanda assessed as functions of body weight, sex, temperature, and food quality.

\section{Material and methods}

Material: The dab Limanda limanda IINA EUS (Family: Pleuronectidae) is a marine fish, occurring in the North. Sea. Its distribution extends from the Biskaya to the Barents Sea; it is also found on the continental shelf of Iceland and in the western Baltic Sea. In this vast area, $L$. limanda is most abundant in the southern North Sea at depths of 20 to $40 \mathrm{~m}$. With increasing water depth, the number of individuals per unit space decreases; at $100 \mathrm{~m} . L$. limanda is already scarce; it is completely absent at depths of more than $200 \mathrm{~m}$. L. limando also occurs in brackish waters, but in less numbers (RÜHMER, 1954; LUNDBECK, 1955).

The Limanda limanda used in the present study were procured near Helgoland in the southern North Sea. During the years $1966-1967$ the temperature of surface water at 'Kabeltonne-Helgoland' ranged from $1.9^{\circ}$ to $17.3^{\circ} \mathrm{C}$; the lowest winter and highest summer means were $2.9^{\circ}$ and $16.5^{\circ} \mathrm{C}$, respectively, and daily fluctuations ranged from $1^{\circ}$ to $2^{\circ} \mathrm{C}$, being higher along the shore (courtsey: Dr. E. HAGMErer and Herr E. Harms; Biologische Anstalt Helgoland). During the winter months, the larger dabs leave the swiftly cooling coastal waters for the open sea. Over the winter months they stay at some distance from the coast and, after spawning, return to the spring-warmed shallow coastal waters (BoHL, 1957). As temperature of the open waters does not sink below $3{ }^{\circ} \mathrm{C}$, it is reasonable to conclude that the annual temperature variations to which the dab population is subjected range from $3^{\circ}$ to $16.5^{\circ} \mathrm{C}$.

During the same period, the range of salinity variations was rather narrow; the monthly means varied around $30 \%$, with maximum and minimum salinities of 28 and $34 \%$, respectively.

Methods: Limanda limanda were collected by the research cutter "Uthorn"; several collections were made during the years 1966-1967. The duration of trawling was restricted to about 15 to $20 \mathrm{~min}$ in order to reduce injuries. The dabs caught were immediately transferred into wooden troughs with running sea water and brought to the laboratory on Helgoland, where they were stocked in a large concrete tank. In general, highest mortality rates occurred during the first two or three days. Individuals which survived this period usually remained healthy afterwards.

Diseases: A day or two after the arrival of a new dab collection, a number of individuals suffered from the "red disease" said to be caused by the bacterium Vibrio anquillarium (SINDRRMANN, 1966); the symptoms were typical: reddening of the dorsal or ventral fin close to the caudal fin, or the caudal fin, and subsequent loss of the infected fin area; these individuals died within a week. Another frequent disease was "intramuscular lesions", causing deep wounds and eventual death. This disease appeared to be similar to the one described by DANNEvig and HANSEN (1952) in the plaice Pleuronectes platessa infected by the bacterium Pseudomonas dermis. All individuals showing symptoms of infections or injury were immediately removed from the tank. A few experimental individuals showed the symptoms of both diseases; when an individual ceased to feed, it was eliminated from the experiment. Though a bordering wooden frame was placed on each aquarium to prevent the experimental individuals from jumping out, there were instances in which dabs jumped the frame and were found dead on the floor next morning. These also had to be eliminated from the experiment; as in BÜCKMANN's (1952) experiments, no compensatory individual was introduced to replace losses due to disease or jumping.

Acclimation: Acclimation (used synonymously with acclimatization, e.g. BoLLock, 1955; KINNE, 1964) to test temperatures was gradual, i.e. at the rate of $1 \mathrm{C}^{\circ}$ per day until the required temperature level was reached; the fishes were then left at that temperature level for a minimum period of 15 days and, in the case of $3^{\circ} \mathrm{C}$ (from $8^{\circ} \mathrm{C}$ ), 20 days (BRETT, 1956). During the period of acclimation, the dabs were "trained" to feed ad libitum.

Temperature: Experiments were performed in cement aquaria of about 2001 capacity $(125 \times 80 \times 20$ 
cm); 8 such aquaria were available, so that 8 experiments could be carried out simultaneously. Sea water was pumped into the laboratory reserve tank, from where it was allowed to percolate through fine sand kept in a large filter tank; the filtered sea water was then run into a cooling-aggregate (Linde, Solekühler) with a capacity of $6,000 \mathrm{Cal} / \mathrm{h}$. From this aggregate, cooled or warmed sea water was run into branch pipes, which continuously fed the aquaria with running sea water. The outflowing water was received in the stock tank, vigorously aerated, and again run into the cooling-aggregate. Once a week, fresh sea water was added from the reserve tank, while emptying the used water from the stock tank. Only at $18^{\circ} \mathrm{C}$, in addition to warming in the aggregate, the water had to be heated by attaching separate thermo-regulating heaters to the walls of the aquaria. The temperature was maintained constant within $\pm 0.4^{\circ} \mathrm{C}$, except for rare cases when the temperature varied about $\pm 1.6^{\circ} \mathrm{C}$.

Light and location: The experimental aquaria were set up in a laboratory where, except during observation and feeding, there was no other disturbance. Glass windows on three sides of the laboratory let in natural sunlight. Experiments at higher temperature levels were carried out during summer, those at low temperature levels during winter, with a view to provide, simultaneously, long and short day light conditions, respectively.

Experimental food: Limanda limanda has been reported to feed on a number of invertebrates, chiefly crustaceans, molluses and polychaetes (KÜHI, 1961). In preliminary experiments (June-July, 1966) the fish were fed Crangon crangon (previously frozen) and subsequently found to evacuate faecal pellets which were hardly digested. DAwns (1930) observed the same phenomenon in plaice, Pleuronectes platessa, frequently fed on the mussel Mytilus edulis. The dab tends to feed on whatever food is offered, irrespective of incomplete digestion and absorption. Incompletely digested faecal pellets accumulated in such quantities in the aquaria that, even with regular siphoning once a day, the aquaria remained dirty. Finally, herring and cod meat were chosen and found to be digested fully. Herring Clupea harengus was obtained from the aquarium of the Biologische Anstalt Helgoland (Herr A. HoutMANN); cod Gadus morhua was purchased from a private firm. The food was preserved at $-20^{\circ} \mathrm{C}$ in a deep freezer; it was quite uniform in chemical composition and calorific properties (Table 1).

Feeding: The dabs were fed until satiation once a day; those kept at $3^{\circ}, 8^{\circ}$ and $13^{\circ} \mathrm{C}$ (herring-fed) at about 11 a.m., the others at about 3 p.m. The frozen food was allowed to thaw (without heating) 2 to $3 \mathrm{~h}$ before feeding; the flesh was then blotted and cut into small weighed pieces. Feeding lasted for about $10 \mathrm{~min}$. The fishes were killed 29 days after initiation of the experiment in order to estimate the amount of food converted.
The "sacrifice method" described by MAYNARD and LoosLI (1962) was employed. It is generally used to test the growth of laboratory mammals fed different foods. This procedure was first employed in experiments with fishes by GERKING (1952, 1954, 1955), later also by Menzec $(1959,1960)$ and Pandtan $(1967 \mathrm{a}, \mathrm{b}$, c, d). A group of 7 to 10 individuals of dab of the same sex and similar $( \pm 10 \%)$ body weight were taken from the stock tank; all individuals had been starved for 2 days in order to empty their alimentary canals. Five individuals (the experimental ones) were, after weighing, transferred into the experimental aquarium, while the others were weighed and killed for calorific estimations. Conversion of food into body substance was estimated by subtracting the calorific content of the experimental fish at the beginning of the experiment from the content at the end of the experiment.

Table 1. Calorific content and composition of food (meat of herring Clupea harengus and cod Gadus morhua)

\begin{tabular}{lcc}
\hline Food & Mean values & Coefficient of variation \\
\hline Herring meat & & \\
$\quad$ Water & $68.8 \% \pm 1.2$ & $1.7 \%$ \\
$\quad$ Ash & $4.2 \% \pm 0.6$ & $14.2 \%$ \\
$\quad$ Energy & $6411 \mathrm{cal} / \mathrm{g} \pm 103$ & $1.6 \%$ \\
& & \\
Cod meat & & \\
$\quad$ Water & $78.7 \% \pm 0.4$ & $0.5 \%$ \\
Ash & $4.4 \% \pm 0.4$ & $9.1 \%$ \\
Energy & $5339 \mathrm{cal} / \mathrm{g} \pm 96$ & $1.8 \%$ \\
\hline
\end{tabular}

Weighing: After removing adhering water particles, live weights of the fishes were made in a Mettler single pan balance to an accuracy of $\pm 0.1 \mathrm{~g}$; in this balance, weighing could be performed within a few seconds so that the fish were little disturbed. The dried fishes were also weighed in this balance. The food was weighed in a balance with an accuracy of $\pm 10 \mathrm{mg}$. All samples used for estimation of ash and calorific contents were weighed in a Sartorius balance (Type 2604; sensitivity $0.01 \mathrm{mg}$ ).

Drying and homogenization: Calorific analyses were made on material dried in an oven at $80^{\circ} \mathrm{Cfor}$ $24 \mathrm{~h}$; the temperature was then raised to $105^{\circ} \mathrm{C}$ until weight constancy. The entire dry fishes were minced and ground (Braun Coffee Miller, Type KM 32) into fine homogenized powder. Of this, an aliquot was preserved in a glass vial kept in a desiccator. A sample of about 150 to $200 \mathrm{mg}$ of the homogenized powder was pressed into a pellet in a copper pelletor; the pellet was kept in an oven, maintained at $80^{\circ} \mathrm{C}$ for a minimum period of $20 \mathrm{~min}$, untilit was weighed previous to calorific analysis.

Calorific contents were determined using a PARR 1412 semi-micro bomb calorimeter, following the 
standard procedure described in the instructions for Parr bomb calorimetry Nos. 128 and 130. For every 10 to 12 estimates the bomb was standardized using a pellet of standard Benzoic acid. In a few cases the sample was not completely oxidized; the results obtained in these instances were discarded. The values for ash contents of the samples used for calorimetry varied from 12 to $17 \%$; only in a few cases ash contents of about $20 \%$ were recorded. Since ash contents never exceeded $25 \%$ in any of the samples, no special correction was made to account for endothermy (PAחNE, 1966).

Ash contents were estimated by maintaining a sample of about $200 \mathrm{mg}$ in a crucible of known weight in a muffle furnace for a period of $5 \mathrm{~b}$ at $600^{\circ} \mathrm{C}$.

\section{Results}

Food intake

Effects of body weight and sex

A total of 18 experiments (9 females, 8 males and 1 juvenile) were carried out to study the effects of body weight and sex on food intake of the dab Limanda limanda. Three to 5 individuals of similar body weight

Table 2. Feeding rate as function of body weight and sex in the dab Limanda limanda. Each value represents the average of 5 individuals, which were fed once a day ad libitum with herring flesh for a period of 28 days at $13^{\circ} \mathrm{C}$

\begin{tabular}{llll}
\hline $\begin{array}{l}\text { Body weight } \\
\text { (g) }\end{array}$ & $\begin{array}{l}\text { Feeding rate } \\
\text { (\% body } \\
\text { weight/day) }\end{array}$ & $\begin{array}{l}\text { Body weight } \\
(\mathrm{g})\end{array}$ & $\begin{array}{l}\text { Feeding rate } \\
\text { (\% body } \\
\text { weight/day) }\end{array}$ \\
\hline Female & & Male & \\
\hline & & & \\
1.1 & 4.0 & 7.1 & 4.0 \\
5.4 & 4.7 & 16.2 & 1.7 \\
16.9 & 2.5 & 35.5 & 3.1 \\
33.1 & 4.4 & 41.2 & 3.5 \\
47.1 & 3.8 & 49.1 & 3.2 \\
61.3 & 3.5 & 77.2 & 2.0 \\
79.5 & 3.4 & 101.2 & 2.4 \\
104.4 & 3.2 & 121.5 & 2.0 \\
115.5 & 2.1 & & \\
150.7 & 1.9 & & \\
\hline
\end{tabular}

and sex were kept in an aquarium in running sea water maintained at $13.0^{\circ} \pm 0.4{ }^{\circ} \mathrm{C}$. They were fed herring meat once a day, until satiation, for a period of about $10 \mathrm{~min}$. The quantity of food consumed fluctuated considerably from day to day; the range and frequency of these fluctuations are described in the ensuing section. Upon averaging the data obtained, a general trend became apparent. Feeding rate has been expressed as percent body weight/day in order to be able to compare the data with those reported in previous papers. The smallest fish used weighed $1.1 \mathrm{~g}$ and its sex could not be distinguished externally. On an average, it consumed an amount of food equivalent to $4.0 \%$ of its own body weight/day (Table 2). Feeding rate of a female weighing $5.4 \mathrm{~g}$ was $4.7 \%$ body weight day and thereafter decreased progressively with increasing body weight; the largest female used (150.7 g) consumed $1.9 \%$ body weight/day. Among the males a similar trend was apparent. Feeding rate of a male weighing $7.1 \mathrm{~g}$ was only $4.0 \%$ body weight/day; it decreased to $2.0 \%$ body weight/day in a $121.5 \mathrm{~g}$ individual.

The amount of food taken in was greater in females (irrespective of body weight) than in corresponding males; the magnitude of the difference was dependent upon body weight. In individuals of about $6,34,103$ and $122 \mathrm{~g}$ weight, feeding rates of females were 16,42 , 28 and $8 \%$ higher than in the respective males. It is of interest to note that, while males lose about 1 to $2 \%$ body weight, females lose as much as 5 to $7 \%$ body weight during spawning (see also HATANAKA et al., $1956 \mathrm{~b}$, for the Japanese plaice Kareius bicoloratus). This observation suggests that females must store about three times more energy in their gonads than males. Since the feeding experiments were performed during August and September (when the dab begins to accumulate energy for increase of body weight as well as for gonad growth), the extra amount of food consumed by the females may, at least in part, have been utilized for the growth of the developing gonads. However, food intake of larger females was only a little higher than in equal-sized males. As will be shown, these females feed voraciously in subsequent months, even when the temperature is low.

A notable feature in the relationship between feeding rate and body weight of the dab is the absence of a very high feeding rate among individuals of less than $10 \mathrm{~g}$ body weight. A curvilinear trend has been reported for the feeding rate-body weight relation in fishes, e.g. Micropterus salmoides (WImLams, 1959), Epinephelus guttatus (MENzer, 1960), Megalops cyprinoides and Ophiocephalus striatus (PANDTaN, 1967 b). In all these fishes growth rate is fastest during the earliest life stages, and later falls with advancing age (increasing body weight). On the other hand, in the dab as well as in many other flat fishes, growth rate is remarkably slow during the first one or two years, which are followed by a rapid growth phase and eventual decrease in growth rate with increasing age and body weight (WIMPENNY, 1953; BoHL, 1957). The low feeding rates of young dabs may be related to their slow growth rates.

A striking feature noted from daily feeding and observation records is the considerable individual and temporal variations in the feeding rate of Limanda limanda. PALoHenMo and Drckme $(1966 \mathrm{a}, \mathrm{b})$, who reexamined the feeding records available in literature, reported that the temporal and individual variations were remarkably great among the flat fishes Pluero- 
nectes platessa (DAWES, 1930 -31), Limanda yolkahamae and Karieus bicoloratus (HatanaKa et al., 1956a, b).

In the following paragraphs, an attempt is made to provide a quantitative estimate of the temporal variations in food intake of the dab Limanda limanda. Some 9 experiments from the $13^{\circ} \mathrm{C}$ series fed on herring meat were chosen at random; from the respective daily feeding records, the average feeding rate of a single individual for each day was calculated and the values obtained plotted (Fig. 1). None of the test fish

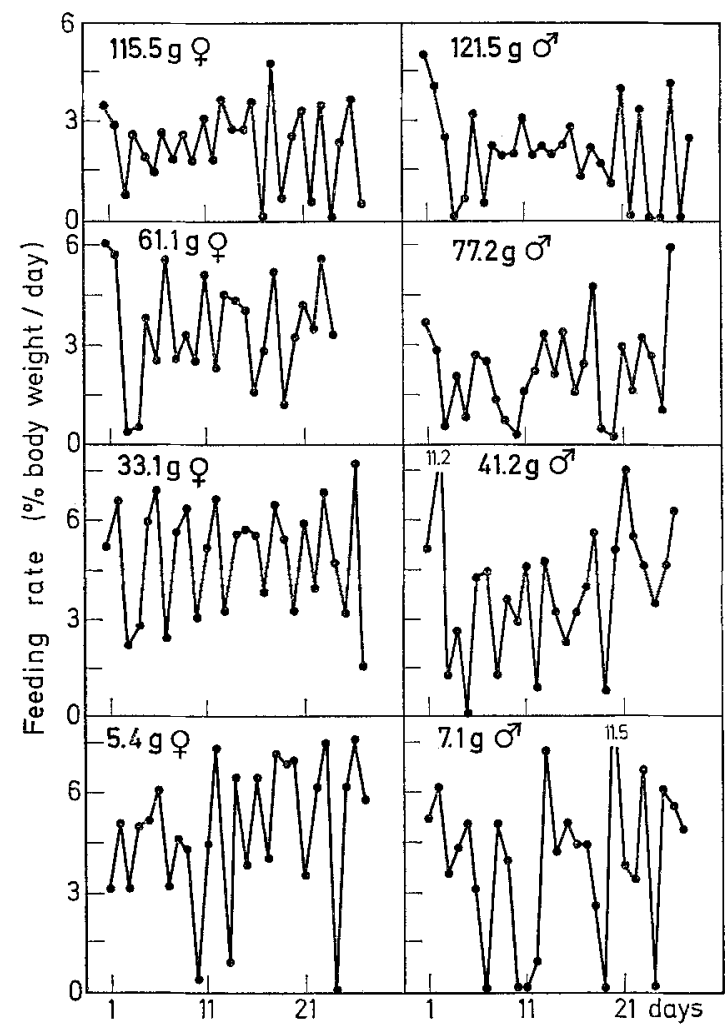

Fig. 1. Day-to-day fluctuations in the rate of food uptake of the dab Limanda limanda. Each value represents the average feeding rate of a single fish; average data are based on 5 individuals fed a restricted supply of herring (Clupea harengus) meat at $13{ }^{\circ} \mathrm{C}$

ever attained a constant feeding level during the 28 day experimental period. A period of heavy feeding (1 to 3 days) is generally followed by a day in which little or no food is ingested, and hence the total intake does not vary greatly from one fortnight to the next.

The first impression that one gains while comparing the heights and frequencies of oscillations in the feeding curves (Fig. 1) is that, with increasing body weight, temporal variations are reduced to a narrow range. However, this is not true. In relation to the lower feeding rate among the larger individuals, the heights of the oscillations are reduced, but not the frequencies. In order to make a more convincing case, $I$ have calculated the standard deviations for the feeding rates of each individual (Table 3).

Considering males of $7.1,41.2,77.2$ and $121.5 \mathrm{~g}$ body weight, the first one has a mean feeding rate of $4.0 \%$ body weight/day with a standard deviation of \pm 2.68 , which amounts to $67.0 \%$ (coefficient of variation) deviation from the mean feeding rate. Similarly, for the remaining randomly chosen 3 test individuals, mean feeding rates are $3.5,2.0$ and $2.0 \%$ body weight $/$ day, with standard deviations of $\pm 2.53,1.38$ and 1.38;

Table 3. Estimates of daily fluctuations in the feeding rate of the dab Limanda limanda. Five individuals of similar body weight, fed at $13^{\circ} \mathrm{C}$ once a day till satiation with herring meat for a period of 28 days

\begin{tabular}{rlll}
\hline $\begin{array}{l}\text { Body weight } \\
\text { (g) }\end{array}$ & Sex & $\begin{array}{l}\text { Mean feeding rate } \\
\text { (\% body weight/ } \\
\text { day) }\end{array}$ & $\begin{array}{l}\text { Coefficient of } \\
\text { variation } \\
(\%)\end{array}$ \\
\hline & & & \\
1.1 & Juvenile & $4.0 \pm 1.78$ & 44.5 \\
5.4 & o & $4.7 \pm 2.04$ & 43.4 \\
33.1 & के & $4.4 \pm 1.77$ & 40.2 \\
61.3 & o & $3.5 \pm 1.39$ & 39.7 \\
115.5 & + & $2.1 \pm 1.24$ & 59.0 \\
7.1 & o & $4.0 \pm 2.68$ & 67.0 \\
41.2 & O & $3.5 \pm 2.53$ & 72.3 \\
77.2 & O & $2.0 \pm 1.38$ & 69.0 \\
121.5 & के & $2.0 \pm 1.38$ & 69.0 \\
& & &
\end{tabular}

their deviation ranges amount to $72.3,69.0$ and $69.0 \%$ of the respective mean feeding rates.

Females of different body weights show about $40 \%$ deviation from the mean feeding rate (only the largest female displayed a higher value of $59.0 \%$ ). Thus, the range of daily variation in feeding rates differs markedly among the sexes, but not among the individuals of different body weights; the range of variation in the male is about $1 \frac{1}{2}$ times greater than that in the female.

\section{Effects of food quality}

In order to find out to what extent food quality modifies the feeding rate-body weight relation, dabs were fed cod (Gadus morhua) meat (series II); the results were then compared with those obtained on dabs fed herring (Clupea harengus) meat (series I). The individuals of series II were kept in groups of five and fed cod meat until satiation once a day for a period of about $10 \mathrm{~min}$, at $13^{\circ} \mathrm{C}$. All other conditions were the same as those in series $\mathrm{I}$, except that the experiments of series I were performed during late August-September 1966, while those of series II were carried out in early June-July 1967. The main differences were the food quality used: herring meat containes $68.8 \%$ water and $6411 \mathrm{cal} / \mathrm{g}$ dry weight, while cod flesh has $78.7 \%$ water and $5339 \mathrm{cal} / \mathrm{g}$ dry weight (Table 1$)$. In other words, $1 \mathrm{~g}$ herring meat (wet weight) yields as 
much as 2001 calories, while the same amount of cod meat yields only 1137 calories; thus, for the same volume or weight of food, herring meat supplies nearly 2 times more energy.

As in series I, feeding rate decreases with increasing body weight of the test individuals used in series II. A female dab weighing $6.2 \mathrm{~g}$ consumed $4.8 \%$ body weight/day, and feeding rate decreased to $1.2 \%$ body weight/day in a $156.3 \mathrm{~g}$ individual; it was $5.4 \%$ body weight/day in a male of $14.1 \mathrm{~g}$ and progressively decreased to $1.6 \%$ body weight/day (Fig. 2).

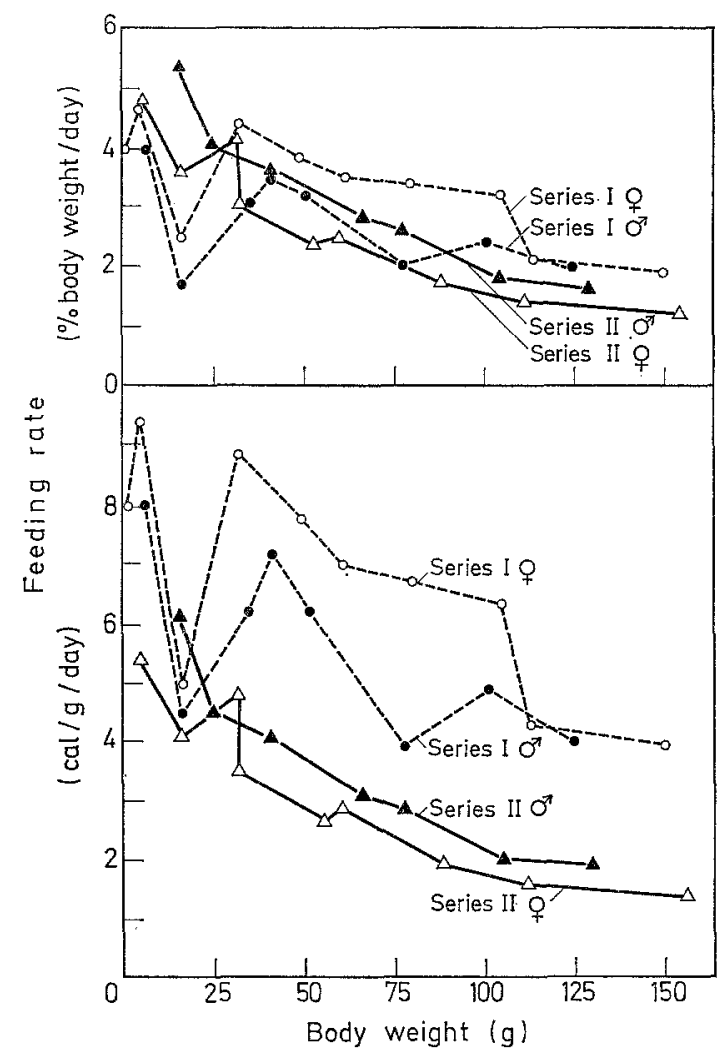

Fig. 2. Feeding rate as function of body weight of Limanda limanda fed a restricted supply of herring (Clupea harengus) meat (series I) or cod (Gadus morhua) meat (series II) at $13^{\circ} \mathrm{C}$

However, there were remarkable and unexpected differences: (1) within series II, the feeding rate of males was higher than that of females, just the reverse of what had been observed in series $\mathbf{I}$. The difference in feeding rate between the sexes within series II was about $0.3 \%$ body weight/day or $0.4 \mathrm{cal} / \mathrm{g} / \mathrm{day}$, and this magnitude of difference was the same throughout the weight-range tested. (2) Irrespective of body weight, feeding rate in both sexes was slightly less in series II than in series I. However, this slight difference, when expressed in cal/g/day becomes considerable (Fig. 2). The magnitude of the difference was again dependent on both sex and body weight. Average daily food intake of a dab female of about $6 \mathrm{~g}$ body weight was $4.7 \%$ of its body weight in the case of herring meat $(9.4 \mathrm{cal} / \mathrm{g} /$ day), and $4.8 \%$ in the case of cod meat ( $5.4 \mathrm{cal} / \mathrm{g} / \mathrm{day})$. Although there was a little difference in the weight of food consumed, the herring-fed dabs received about $70 \%$ more energy than the cod-fed individuals. Among the fast-growing females of the size range 33 to $115 \mathrm{~g}$ (BoHL, 1957; p. 19), however, even greater differences became apparent. In females of about 50 and $100 \mathrm{~g}$, feeding rates were 2.4 and $1.6 \%$ body weight/day (2.7 and $1.7 \mathrm{cal} / \mathrm{g} /$ day) when on a cod meat diet, but 3.9 and $3.2 \%$ body weight/day ( 7.7 and $6.3 \mathrm{cal} / \mathrm{g} / \mathrm{day})$ when on $a$ herring diet. From the point of energy input, individuals fed on herring meat obtained about 3 times more energy than cod-fed dabs. The difference in food intake among the males of series $\mathrm{I}$ and $\mathrm{II}$ was rather less, and uniform throughout the weight-range tested. Thus, irrespective of changes in food quality, individuals of about 41 and $78 \mathrm{~g}$ body weight consumed 3.5 and $2.1 \%$ body weight/day, respectively.

\section{Effects of temperature}

The annual temperature variation to which the dab population is subjected in its natural habitat ranges from about $3^{\circ}$ to $16.5^{\circ} \mathrm{C}$. In the present investigation, modifying effects of temperature on the feeding ratebody weight relationship have been studied, choosing the following temperature levels: $3^{\circ}, 8^{\circ}, 13^{\circ}$ and $18^{\circ} \mathrm{C}$. As many as 60 experiments were carried out during the period from October 1966 to November 1967. In general, experiments at higher temperature levels were performed during summer, those at lower temperature levels during fall and early winter. No experiment was made during March and April 1967, when the dabs spawn. Eight experiments were set up at a given temperature level and each experiment lasted for a period of about 28 days (except for one series at $3{ }^{\circ} \mathrm{C}$, which had to be terminated after 10 days feeding, as the test individuals began to spawn).

Average feeding rates of the tested fishes at different temperature levels are presented in Table 4. Except for the females at $8^{\circ} \mathrm{C}$, feeding rate decreased with increasing body weight. In males of less than $35 \mathrm{~g}$, feeding rate decreased in this order: $18^{\circ}, 13^{\circ}, 8^{\circ}$ and $3^{\circ} \mathrm{C}$, while in the larger individuals tested, the decrease was in the order $13^{\circ}, 18^{\circ}, 8^{\circ}, 3^{\circ} \mathrm{C}$. The following are the orders in which feeding rate decreased in the females: group 1 (less than $30 \mathrm{~g}$ ): $13^{\circ}>18^{\circ}>8^{\circ}>3^{\circ} \mathrm{C}$; group 2 (between 31 and $80 \mathrm{~g}$ ): $18^{\circ}>13^{\circ}>8^{\circ}>3^{\circ} \mathrm{C}$; group 3 (heavier than $80 \mathrm{~g}$ ): $8^{\circ}>18^{\circ}>13^{\circ}>3^{\circ} \mathrm{C}$.

Sixteen experiments were performed at $3^{\circ} \mathrm{C}$; at this low temperature dabs of less than $60 \mathrm{~g}$ did not feed at all; 2 to 3 individuals died during each of these experiments. It may be presumed that the lower lethal temperature of these small dabs lies near $3{ }^{\circ} \mathrm{C}$. SrMPsoN (1953), who investigated the mortality of fish and the distribution of plankton in the southern North 
Sea during the severe cold winter 1946-1947, reported $0.0^{\circ}$ to $0.9^{\circ} \mathrm{C}$ as lower lethal temperatures for the dab. It is interesting that females weighing less than $61.7 \mathrm{~g}$, and males of less than $44.0 \mathrm{~g}$ body weight, did not feed throughout the 26 day experimental period at $3{ }^{\circ} \mathrm{C}$.

Table 4. Feeding rate as a function of temperature in the dab Limanda limanda. Each value represents the average of 2 individuals, which were fed once a day ad libitum with cod flesh for a period of 28 days. 0.0 indicates that the test individuals did not feed throughout the experiment

\begin{tabular}{|c|c|c|c|}
\hline $\begin{array}{l}\text { Body weight } \\
\text { (g) }\end{array}$ & $\begin{array}{l}\text { Feeding rate } \\
\text { (\% body } \\
\text { weight/day) }\end{array}$ & $\begin{array}{l}\text { Body weight } \\
\text { (g) }\end{array}$ & $\begin{array}{l}\text { Feeding rate } \\
\text { (\% body } \\
\text { weight/day) }\end{array}$ \\
\hline$\overline{\text { Female }}$ & & Male & \\
\hline \multicolumn{4}{|l|}{$3^{\circ} \mathrm{C}$} \\
\hline 10.3 & 0.0 & 10.0 & 0.0 \\
\hline 21.3 & 0.0 & 20.1 & 0.0 \\
\hline 39.9 & 0.0 & 32.2 & 0.0 \\
\hline 61.7 & 0.0 & 44.0 & 0.0 \\
\hline 63.8 & 1.2 & 59.7 & 1.0 \\
\hline 84.9 & 0.9 & 81.7 & 0.5 \\
\hline 121.2 & 0.7 & 114.4 & 0.6 \\
\hline 163.1 & 0.8 & & \\
\hline 274.1 & 0.2 & & \\
\hline \multicolumn{4}{|l|}{$8^{\circ} \mathrm{C}$} \\
\hline 2.7 & 0.0 & 13.2 & 0.6 \\
\hline 16.4 & 0.5 & 28.0 & 1.4 \\
\hline 17.4 & 0.5 & 38.7 & 1.7 \\
\hline 36.7 & 1.4 & 61.3 & 1.9 \\
\hline 54.2 & 1.6 & 80.0 & 0.9 \\
\hline 78.7 & 1.6 & 101.2 & 0.8 \\
\hline 107.1 & 2.0 & 124.7 & 1.2 \\
\hline 130.9 & 2.1 & & \\
\hline 168.5 & 1.5 & & \\
\hline \multicolumn{4}{|l|}{$13^{\circ} \mathrm{O}$} \\
\hline 6.2 & 4.8 & 14.1 & 5.4 \\
\hline 16.4 & 3.6 & 25.6 & 4.0 \\
\hline 31.5 & 4.2 & 41.2 & 3.6 \\
\hline 32.7 & 3.1 & 65.8 & 2.8 \\
\hline 52.8 & 2.4 & 77.6 & 2.6 \\
\hline 59.7 & 2.5 & 104.3 & 1.8 \\
\hline 87.6 & 1.7 & 129.8 & 1.6 \\
\hline 113.6 & 1.4 & & \\
\hline 156.3 & 1.2 & & \\
\hline \multicolumn{4}{|l|}{$18^{\circ} \mathrm{C}$} \\
\hline 8.2 & 4.2 & 10.1 & 6.9 \\
\hline 16.4 & 2.3 & 34.3 & 4.4 \\
\hline 35.5 & 3.2 & 58.1 & 1.9 \\
\hline 45.5 & 3.4 & 96.7 & 1.6 \\
\hline 66.8 & 2.6 & & \\
\hline 84.2 & 2.2 & & \\
\hline 110.3 & 1.9 & & \\
\hline 160.7 & 1.3 & & \\
\hline
\end{tabular}

They refused to feed even when the food was left for a longer period (even throughout the entire day). Among the larger individuals which were feeding, food uptake was very irregular and their responses were not normal; they were lying around inactively in the corners of the aquaria, close to each other, or sometimes even partially over each other. At $8^{\circ} \mathrm{C}$, similar behaviour was observed among individuals of $2.7 \mathrm{~g}$; on the other hand, at temperatures of $13^{\circ}$ and $18^{\circ} \mathrm{C}$, the dabs were either actively swimming or lying apart from each other on the ground. The small amount of food con-

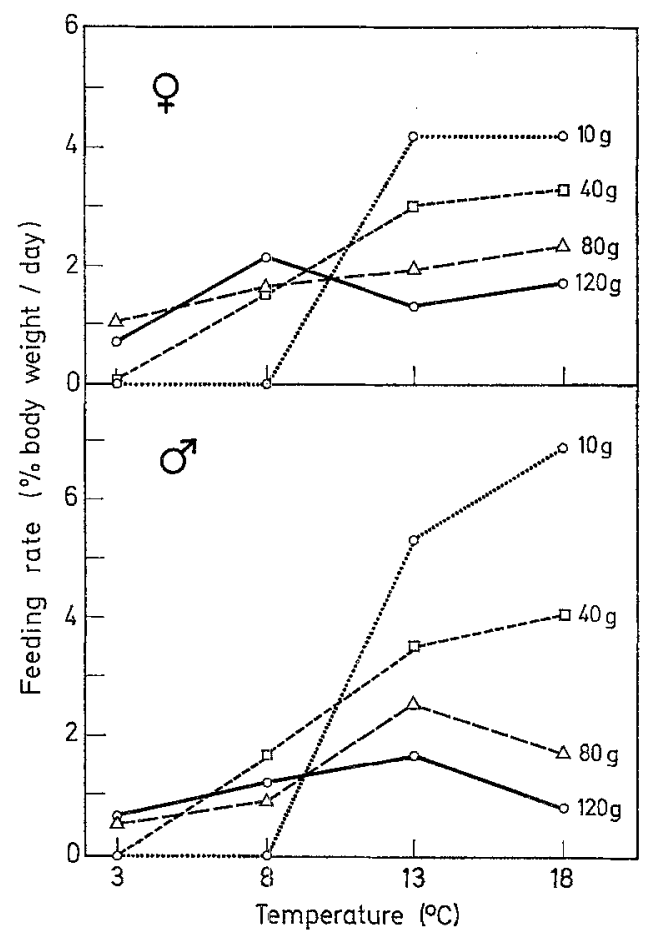

Fig. 3. Feeding rates of Limanda limanda fed a restricted supply of cod meat at 4 different temperature levels

sumed by the $13.2 \mathrm{~g}$ male and $16.4 \mathrm{~g}$ female at $8^{\circ} \mathrm{C}$ was ingested by them in the early half of the experiment; in the latter half, they completely ceased to feed. Feeding rate of these test individuals was about $0.6 \%$ body weight/day as against 5.4 and $3.6 \%$ body weight/ day at $13{ }^{\circ} \mathrm{C}$, respectively. While dabs weighing less than $13 \mathrm{~g}$ did not feed at $8^{\circ} \mathrm{C}$ throughout the experiment, females of more than $80 \mathrm{~g}$ fed at maximum rates.

In February 1968, 40 specimens of Limanda limanda were collected near Helgoland and their stomach contents analysed. Most individuals weighing less than $50 \mathrm{~g}$ had virtually no food in their stomachs, while the others contained traces of food. Of the 3 larger individuals caught (about $80 \mathrm{~g}$ ), two contained a fair amount of food, while the other had a stomach full of food. It is well known that temperate fishes cease to feed during winter (NIKOLSKY, 1963; p. 258). Interestingly, DAwES (1930-31) observed that the plaice Pleuronectes platessa ceased to feed in the latter half of November, when the habitat temperature was less than $10^{\circ} \mathrm{C}$; however, DAwEs (p. 908) reported that, during the same period, 3 individuals (2 우우 and 1 ) ), weighing more than $100 \mathrm{~g}$, continued to feed. 
In view of the complicated trends observed, I have attempted to present a generalized picture of the effects of different temperature levels on food intake of the dab. The feeding rates of 4 females and 4 males of different body weights are given in Fig. 3. Three interesting conclusions may be drawn. (1) The "normal temperature" for the test individuals varies with the body weight. Under "normal temperature" or "temperature norm" is understood: the range of environmental temperature "which allows the undisturbed functioning of metabolic processes, i.e. the processes which convert and use material for maintenance, growth, reproduction and repair and which make energy available to the organism" (KINNE, 1960;p.313). The lowest temperature at which normal feeding is possible lies between $8^{\circ}$ and $13^{\circ} \mathrm{C}$ for dabs of less than $13 \mathrm{~g}$ (about 2 years old), between $3^{\circ}$ and $8^{\circ} \mathrm{C}$ for dabs between 13 to $60 \mathrm{~g}$, and just above $3{ }^{\circ} \mathrm{C}$ for dabs over $60 \mathrm{~g}$. (2) The feeding behaviour of smaller dab changes considerably as a function of temperature; they either feed and gorge themselves as at $13^{\circ}$ and $18^{\circ} \mathrm{C}$, or cease to feed completely as at $8^{\circ}$ and $3^{\circ} \mathrm{C}$. With increasing body weight (age), the magnitude of the temperature effect is progressively reduced. (3) Females of less than $10 \mathrm{~g}$ feed at maximum rates between $13^{\circ}$ and $18^{\circ} \mathrm{C}$; larger females of less than $80 \mathrm{~g}$ reach their maximum food intake at $18^{\circ} \mathrm{C}$; females weighing more than $80 \mathrm{~g}$ attain their maximum already at $8^{\circ} \mathrm{C}$. Males of less than $40 \mathrm{~g}$ feed at maximum rates at $18^{\circ} \mathrm{C}$, while larger ones reach their maximum food intake at $13{ }^{\circ} \mathrm{C}$. There is a decrease in optimum temperature for maximum feeding rates with increasing body weight (age).

\section{Food conversion}

Changes in composition and calorific content of test fishes fed cod or herring meat

\section{Effects of body weight and sex}

Water content values obtained for females of Limanda limanda before feeding at $13{ }^{\circ} \mathrm{C}$ (series I) revealed a progressive decrease from $85.1 \%$ in a female of $1.1 \mathrm{~g}$ to $75.3 \%$ in a female of $150.7 \mathrm{~g}$ (the heaviest female used). A similar decrease of body water content with increasing body weight was also noted among males. Average water contents of all females and males were $77.2 \%$ and $76.3 \%$, respectively. Body water content values of dab reported in literature range from 83.1 to $78.1 \%$ (VINOGRADOv, $1953 ;$ p. 481). As found in the present study, JAKovLev (1957) reported an indirect correlation between water content and body size (length) of the dab L. limanda. Calorific contents of individuals of $L$. limanda used in the present study varied from 4569 to $5564 \mathrm{cal} / \mathrm{g}$ dry weight ${ }^{1}$, ash contents from 19.0 to $11.3 \%$. No definite correlation between body weight and calorific content was apparent. Although ash content averaged $14.8 \%$ for males as well as females, females, on the whole, contained more energy $(5219 \mathrm{cal} / \mathrm{g})$ per unit weight than males $(5132 \mathrm{cal} / \mathrm{g})$. On an average, both sexes contained, at the beginning of the experiment, $76.8 \%$ water, $14.8 \%$ ash and $5181 \mathrm{cal} / \mathrm{g}$ (Table 5).

Compared to these high water and ash contents of the dabs, herring meat has lower water $(68.8 \%)$ and ash $(4.2 \%)$ contents per unit weight than that of the dabs at the commencement of the feeding experiments. Therefore, considerable changes in the composition of dab fed herring meat for 28 days may be expected. The average values obtained for herring-fed females were $74.1 \%$ for water, $12.1 \%$ for ash, and $5659 \mathrm{cal} / \mathrm{g}$ for energy; the respective values for males were more or less the same except for calorific content $(5472 \mathrm{cal} / \mathrm{g}$; Table 5). On the whole, there was a considerable increase in calorific content (5575 cal/g; 7.6\% more energy than initially), while water $(2.5 \%)$ and ash $(2.7 \%)$ contents decreased.

Limanda limanda which were to be fed cod meat contained an average of $78.0 \%$ water, $15.7 \%$ ash, and $4983 \mathrm{cal} / \mathrm{g}$ energy (Table 5). The feeding experiments were made during May and June 1967, when the dabs were recovering from spawning. Throughout spawning

1 Unless otherwise qualified, hereafter values for calorific and ash contents are given per dry weight, water content per wet weight.

Table 5. Average changes in the composition of the dab limanda limanda, which received a restricted food supply of herring or cod meat at 3 different temperatures

\begin{tabular}{|c|c|c|c|c|c|c|c|}
\hline \multirow{2}{*}{$\begin{array}{l}\text { Dabs fed at the temperature } \\
\text { level of }\end{array}$} & & \multicolumn{3}{|c|}{ Initial composition } & \multicolumn{3}{|c|}{ Final composition } \\
\hline & & $\begin{array}{l}\text { Water } \\
(\%)\end{array}$ & $\begin{array}{l}\text { Ash } \\
(\%)\end{array}$ & $\begin{array}{l}\text { Energy } \\
(\mathrm{cal} / \mathrm{g})\end{array}$ & $\begin{array}{l}\text { Water } \\
(\%)\end{array}$ & $\begin{array}{l}\text { Ash } \\
(\%)\end{array}$ & $\begin{array}{l}\text { Energy } \\
(\text { cal } / g)\end{array}$ \\
\hline $\begin{array}{l}8^{\circ} \mathrm{C} \text {, cod-fed series } \\
18^{\circ} \mathrm{C} \text {, cod-fed series } \\
13^{\circ} \mathrm{C} \text {, series I (herring meat) } \\
13^{\circ} \mathrm{C} \text {, series I (herring meat) } \\
13^{\circ} \mathrm{C} \text {, series I (herring meat) } \\
13^{\circ} \mathrm{C} \text {, series II (cod meat) }\end{array}$ & 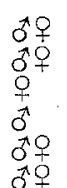 & $\begin{array}{l}75.3 \\
76.4 \\
77.2 \\
76.3 \\
76.8 \\
78.0\end{array}$ & $\begin{array}{l}12.3 \\
17.0 \\
14.8 \\
14.8 \\
14.8 \\
15.7\end{array}$ & $\begin{array}{l}5324 \\
4776 \\
5219 \\
5132 \\
5181 \\
4983\end{array}$ & $\begin{array}{l}75.1 \\
76.2 \\
74.1 \\
74.6 \\
74.3 \\
77.9\end{array}$ & $\begin{array}{l}12.3 \\
16.2 \\
12.1 \\
12.1 \\
12.1 \\
14.8\end{array}$ & $\begin{array}{l}5514 \\
4896 \\
5659 \\
5472 \\
5575 \\
5206\end{array}$ \\
\hline
\end{tabular}


dabs loose a considerable amount of gonadal substance (2 to $7 \%$ of their body weight) containing about $5800 \mathrm{cal} / \mathrm{g}$ (FLÜchtwR and PANDIAN, 1968). This may be the reason for the low calorific content of the individuals used in the present experiments.

The cod meat used as food contained $5339 \mathrm{cal} / \mathrm{g}$, i.e. $7.2 \%$ more energy per unit weight than the dabs at the commencement of feeding (herring meat contains $23.8 \%$ more energy than that of the dab). A 30day feeding period with cod meat enriched the calorific content of the dabs to $5206 \mathrm{cal} / \mathrm{g}$, i.e. the dabs contained, per unit weight, $4.5 \%$ more energy than before the feeding experiment. There was a wide difference in the ash contents (cod meat $4.4 \%$ ash; dab meat before feeding $15.9 \%$ ash), while the difference in water content was very small $(78.7 \%$ water in cod meat; $78.0 \%$ water in dab meat; Table 5). Thirty-day feeding decreased the ash content of the dabs to $14.8 \%$.

Both herring (series I) and cod (series II) feeding decreased the water content (about 1 to $2 \%$ ) of the dabs. The calorific increases per unit dab weight was $7.6 \%$ if herring-fed, but only $4.5 \%$ if cod-fed. In series I, there was a greater decrease in ash content (from 14.8 to $12.1 \%$ ) than in series II (from 15.7 to $14.8 \%$ ).

During the course of experimental feeding at $3{ }^{\circ} \mathrm{C}$, some dabs spawned; unfortunately, these were the only individuals which were feeding amounts equivalent to at least $1 \%$ of their own body weight/day. The other dabs ceased to feed at this low temperature. Since it was not possible to say which of the test individuals spawned, the data obtained on the composition of the $3{ }^{\circ} \mathrm{C}$ dabs have been excluded. At $8{ }^{\circ} \mathrm{C}$, individuals of less than $17 \mathrm{~g}$ body weight (used in 4 experiments) did not feed or fed only very little. They starved, and lost considerable body weight. The data obtained on these dabs were also excluded while averaging the values obtained for the other $8{ }^{\circ} \mathrm{C}$ individuals.

Calorific contents of the dabs before feeding averaged $5324 \mathrm{cal} / \mathrm{g}$ at $8^{\circ} \mathrm{C}, 4983 \mathrm{cal} / \mathrm{g}$ at $13^{\circ} \mathrm{C}$, and $4776 \mathrm{cal} / \mathrm{g}$ at $18^{\circ} \mathrm{C}$. After feeding 28 days at $8^{\circ} \mathrm{C}$, 30 days at $13^{\circ} \mathrm{C}$ and 20 days at $18^{\circ} \mathrm{C}$, the resulting calorific contents of the test fishes showed considerable changes; the average energy content values were 5514, 5206 and $4896 \mathrm{cal} / \mathrm{g}$, respectively. At all 3 temperature levels the calorific contents increased per unit dab weight; the increases amounted to $3.6,4.5$ and $2.5 \%$ per unit weight before feeding. Water and ash contents showed no appreciable changes (Table 5).

\section{Efficiency and rate of food conversion}

The total amount of food converted has been estimated by subtracting the energy content of the dabs at the beginning of the experiment from that at the end of the feeding period. In order to compare the data, the average amount of energy converted by a single individual per day has been calculated for each experiment. Gross efficiency of food conversion was calculated by relating the amount of energy converted to the energy contained in the food consumed.

\section{Effects of body weight and sex}

Among the test individuals of series I fed on herring meat at $13{ }^{\circ} \mathrm{C}$, conversion efficiency of the smallest individual ( $1.1 \mathrm{~g}$ ) was $43.2 \%$. It increased to $47.9 \%$ in a female of $33.1 \mathrm{~g}$ body weight and, thereafter, decreased to $34.2 \%$ in the heaviest individual used (150.7 g). Among males a similar trend was apparent;

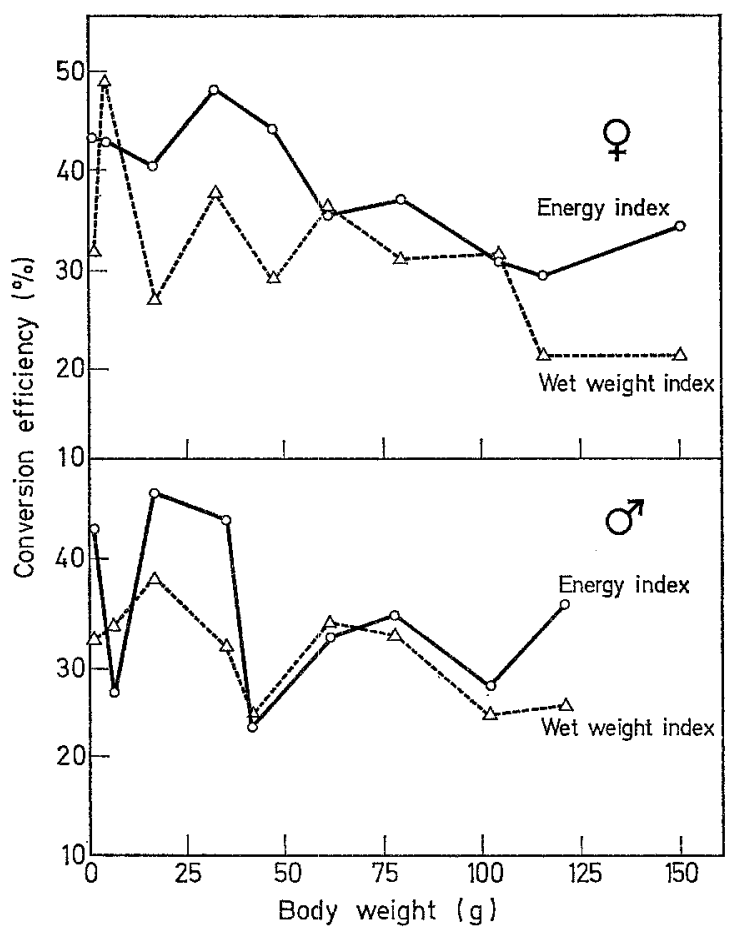

Fig. 4. Food conversion efficiency as function of body weight of Limanda limanda fed a restricted supply of herring meat at $13^{\circ} \mathrm{C}$

an individual of $16.2 \mathrm{~g}$ converted $46.6 \%$ of the energy contained in the food consumed. Conversion efficiency then decreased to $26.8 \%$ in an individual of $101.1 \mathrm{~g}$, although the heaviest male $(121.5 \mathrm{~g})$ showed, unexpectedly, a higher value $(35.4 \%)$. With increasing body weight, conversion efficiency decreased in both sexes. The females were more efficient food converters than the males (Fig. 4).

Hatamaka et al. (1956a) fed the Japanese dab Limanda yokahamae with annelid worms or clam at an ambient temperature of $13.1^{\circ} \mathrm{C}$. They also found an indirect relation between body weight and conversion efficiency; the efficiency was $21.8 \%$ for an individual of $68 \mathrm{~g}$, and decreased to $15.8 \%$ in a larger individual 
of $148 \mathrm{~g}$. The values reported by HaTaNaka et al. for clam-fed dabs are also low, and not very different from those obtained for the annelid-fed dabs. On the whole, $L$. limanda appeared to be about 2 times more efficient than $L$. yokahomae. With a view to checking my data, I have calculated the efficiency relating the wet weight gained to the wet weight of food consumed (as did Hatanaka et al.). Most of these values are far lower than the corresponding values based on "energy index" (Fig. 4). Even the values based on "wet weight index" are $1 \frac{1}{2}$ times higher than those reported for the Japanese dab. This is because $1 \mathrm{~g}$ wet weight of the dab L. limanda contains 1201 calories (based on average values of $76.8 \%$ water, $5181 \mathrm{cal} / \mathrm{g}$ ), while $1 \mathrm{~g}$ herring meat has 2001 calories. In other words $1 \mathrm{~g}$ herring (fresh weight) corresponds to about $1.7 \mathrm{~g}$ dab (fresh weight). It is likely that $1 \mathrm{~g}$ annelid or clam used as food corresponded to $1 \mathrm{~g}$ Japanese dab, from the point of wet weight, as well as energy.

\section{Effect of food quality}

Fig. 5 shows the efficiency values obtained for dabs of series II fed with cod meat at $13^{\circ} \mathrm{C}$. The efficiency decreased from $34.1 \%$ in a female of $6.2 \mathrm{~g}$ to $28.1 \%$ in a female of $156.3 \mathrm{~g}$ body weight. A similar trend was obtained for the males. The efficiency decreased from $33.1 \%$ in the smallest male $(6.2 \mathrm{~g})$ to $19.9 \%$ in a male of $129.8 \mathrm{~g}$ body weight. As in series I, cod-fed males

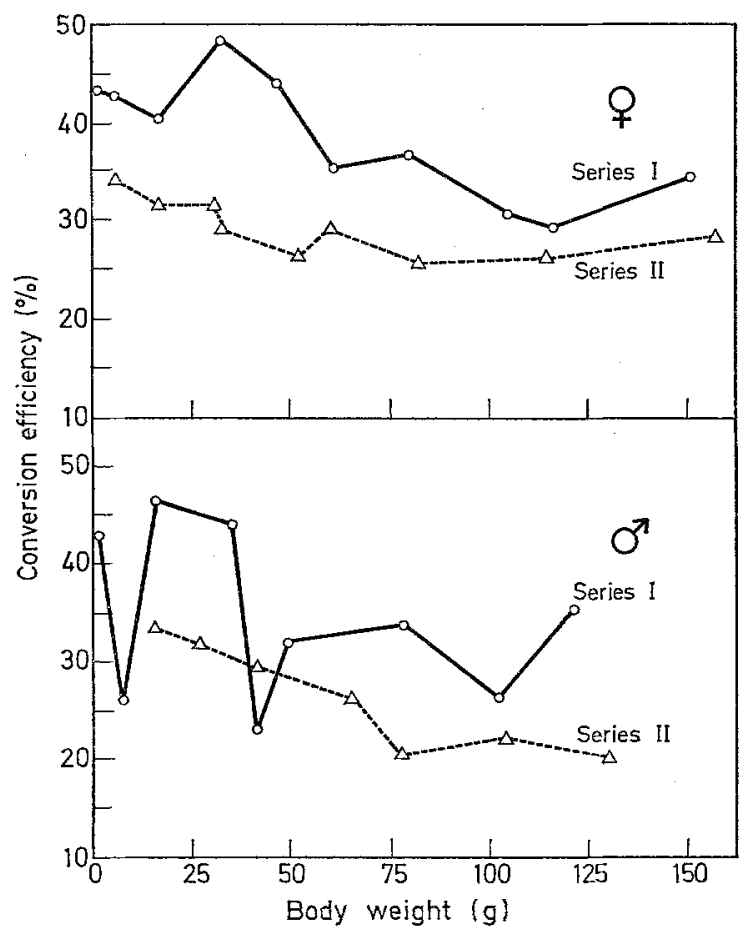

Fig. 5. Food conversion efficiency as function of body weight of Limanda limanda fed a restricted supply of herring meat (series I) or cod meat (series II) at $13^{\circ} \mathrm{C}$ were less efficient than the corresponding females. Herring-fed dabs, on the whole, were more efficient converters than cod-fed dabs. As $1 \mathrm{~g}$ wet weight of cod meat contains 1137 calories, and $1 \mathrm{~g}$ wet weight of dab 1096 calories, there was no appreciable difference between the efficiency values based on "wet weight index" and "energy index".

\section{Effects of temperature}

As already reported, test individuals fed at $3{ }^{\circ} \mathrm{C}$ ceased to feed, or fed only a little (less than $1 \%$ body weight/day), and some spawned during the experiment. Therefore, only results obtained for individuals fed at $8^{\circ}, 13^{\circ}$ and $18^{\circ} \mathrm{C}$ are reported here.

Individuals weighing more than $30 \mathrm{~g}$ reached, in both sexes, their maximum efficiency at $8^{\circ} \mathrm{C}$ (Fig. 6). Females of 50 to $150 \mathrm{~g}$ converted as much as $40 \%$ of the consumed food at $8{ }^{\circ} \mathrm{C}$, and only about $22 \%$ at $18^{\circ} \mathrm{C}$; the males displayed a similar trend. To yield $1 \mathrm{~g}$ body substance, a dab of $90 \mathrm{~g}$ body weight must eat $5 \mathrm{~g}$ food at $18^{\circ} \mathrm{C}$, but only $2.5 \mathrm{~g}$ food at $8^{\circ} \mathrm{C}$.

Among males and females of more than $30 \mathrm{~g}$, the efficiency decreased in the order $8^{\circ}, 13^{\circ}, 18^{\circ} \mathrm{C}$. For smaller fishes, the decreasing order was $13^{\circ}, 18^{\circ}, 8^{\circ} \mathrm{C}$. Female dabs attain sexual maturity at a body weight

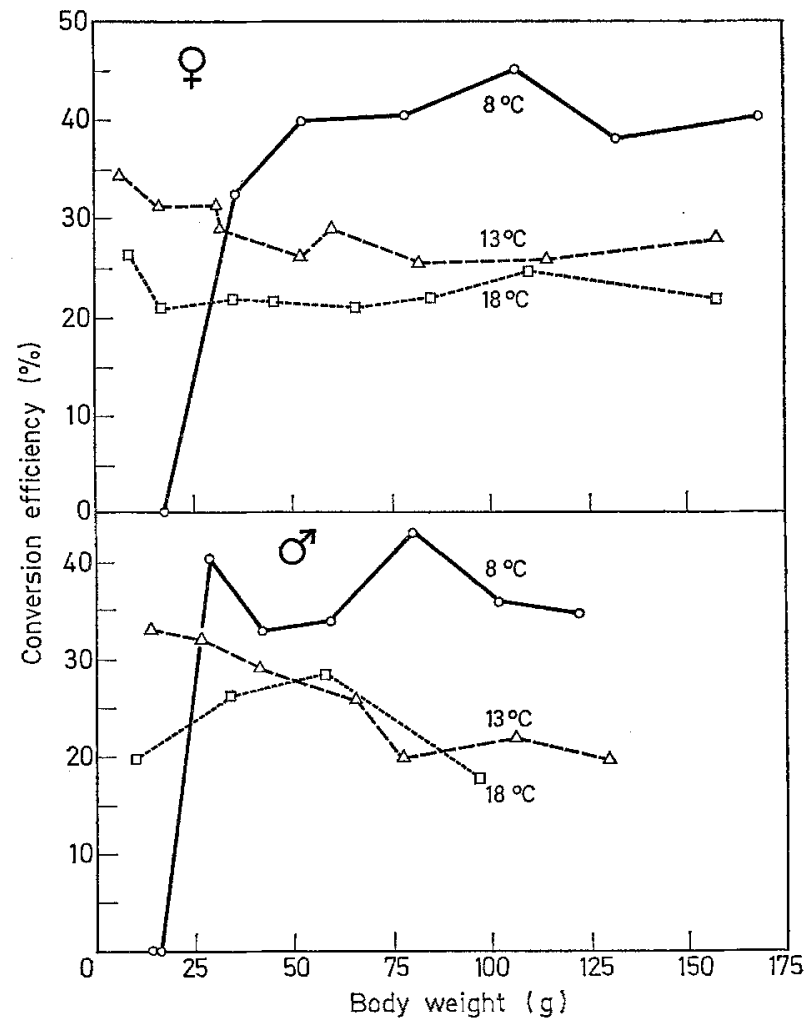

Fig. 6. Food conversion efficiency of the dab Limanda limanda fed a restricted supply of cod meat at 3 different temperature levels 
of about $40 \mathrm{~g}$, the males at about $30 \mathrm{~g}$ (BoHL, 1957). Conversion efficiency of sexually mature and actively reproducing dabs $(>40 \mathrm{~g})$ attains a maximum at $8^{\circ} \mathrm{C}$; the maximum is $13{ }^{\circ} \mathrm{C}$ in young, immature dabs $(<40 \mathrm{~g})$. Thus, optimum temperature for efficient conversion decreases with increasing body weight.

\section{Conversion rate}

Fig. 7 shows that conversion rates of herring-fed dabs were about 2 to 4 times higher than those of codfed dabs. The magnitude of this difference depends

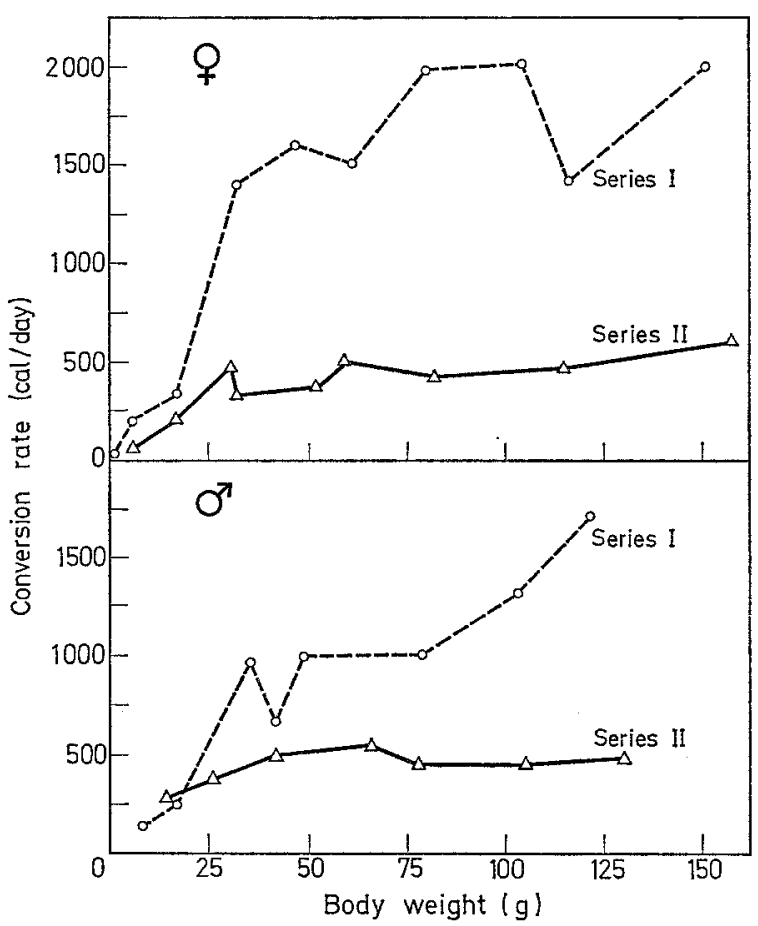

Fig. 7. Food conversion rate of Limanda limanda as function of body weight. The test individuals were offered a restricted supply of herring meat (series I) or cod meat (series II) at $13^{\circ} \mathrm{C}$

upon body weight and sex. A $15 \mathrm{~g}$ individual (series I and II) converts about $150 \mathrm{cal} / \mathrm{day}$; a $100 \mathrm{~g}$ individual of series II, whether male or female, converts about $450 \mathrm{cal} /$ day; a female of $100 \mathrm{~g}$ of series I converts $2000 \mathrm{cal} /$ day, a corresponding male only $1300 \mathrm{cal} /$ day. Among individuals of any body weight, from either series I or II, the conversion rate of the female is greater than that of the corresponding male.

Irrespective of body weight, males reveal fastest conversion at $13{ }^{\circ} \mathrm{C}$ (Fig. 8). The slowest conversion in dabs under $50 \mathrm{~g}$ occurs at $8^{\circ} \mathrm{C}$; in the larger males (over $50 \mathrm{~g}$ ) at $18^{\circ} \mathrm{C}$. Conversion rate decreases in females of more than $50 \mathrm{~g}$ body weight in the order $8^{\circ}$, $18^{\circ}, 13^{\circ} \mathrm{C}$; for smaller females in the order $13^{\circ}, 18^{\circ}, 8^{\circ} \mathrm{C}$. At all 3 temperature levels, conversion rates are higher $2^{*}$ among females than among males, e.g. at $8^{\circ} \mathrm{C}$, a $100 \mathrm{~g}$ male converts $350 \mathrm{cal} / \mathrm{day}$, a female $950 \mathrm{cal} / \mathrm{day}$ (Fig. 8 ).

Quantitative relationships between food intake, metabolism and body weight

The quantitative relationship between food intake and body weight was calculated on the basis of the allometric formula $y=b x^{a}$, where $y$ is metabolism, $x$ body weight, and $a$ and $b$ are constants. As the smaller fishes did not feed at $3^{\circ}$ and $8^{\circ} \mathrm{C}$, data obtained at $13^{\circ}$ and $18^{\circ} \mathrm{C}$ were used. When plotting the average

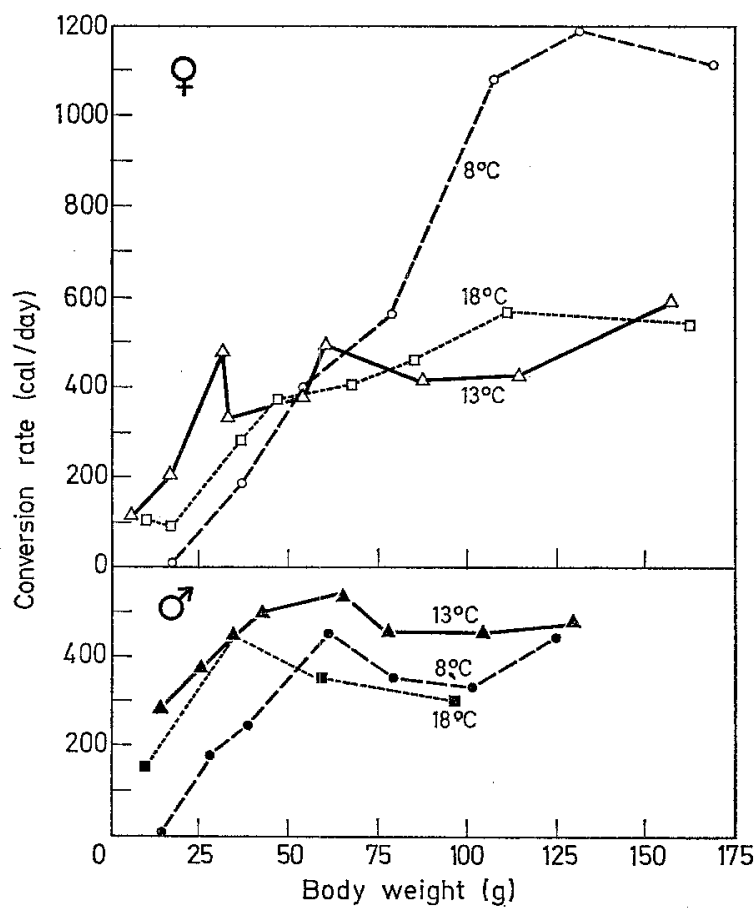

Fig. 8. Food conversion rate of the dab Limanda limanda fed a restricted supply of cod meat at 3 different tem perature levels

daily food intake against body weight in a double logarithmic graph, the difference in food intake between males and females appears to be less significant (Fig. 9). The weight exponents are 0.54 for $13{ }^{\circ} \mathrm{C}$ and 0.57 for $18^{\circ} \mathrm{C}$ (cod meat) and 0.88 for $13{ }^{\circ} \mathrm{C}$ (herring meat). Thus, food quality strongly alters the weight exponent, while temperature changes seem to have little influence. The " $a$ " value is lowest for herring-fed dabs $(92.1 \mathrm{cal} / \mathrm{day})$; it is $178.2 \mathrm{cal} /$ day at $13{ }^{\circ} \mathrm{C}$ and $142.2 \mathrm{cal} /$ day at $18^{\circ} \mathrm{C}$ in cod-fed dabs ${ }^{2}$.

Effects of temperature and food quality on the relation between metabolic rate and body weight have also been calculated using the allometric formula.

2 I am grateful to Prof. Dr. F. Krüger (Biologische Anstalt Helgoland, Hamburg) for his kind evaluation of my calculations. 
I have no direct information on the amount of energy used for metabolism by dabs, but appropriate values can be calculated from data on food intake and food conversion. Following the procedure used by PaLoHeIMo and DrCkIE (1966a), I have employed WINBERG's (1956) "utilization coefficient" for calculating the amount of energy contained in the food absorbed. From these values, the amount of energy contained in the food converted was subtracted to obtain the amount of energy which may have been used for metabolism. The values so obtained were related to body weight in order to calculate ' $a$ ' and ' $b$ ' values. The slopes of the curves (or weight exponents) are 0.61 for $13^{\circ} \mathrm{C}$ and 0.58 for $18^{\circ} \mathrm{C}(\operatorname{cod}$ meat); these curves are

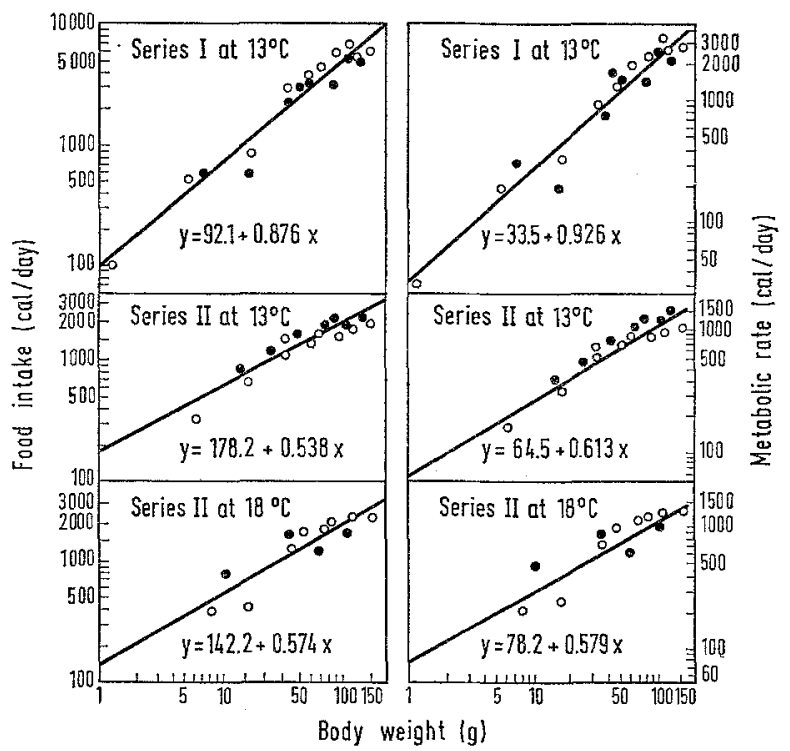

Fig. 9. Quantitative relations of body weight of Limanda limanda to rates of food uptake (left) and metabolism (right). Open circles: females; closed circles: males. Test individuals of series I received herring meat, those of series II cod meat

almost parallel to each other, but differ due to a higher ' $a$ ' value (78.2 cal/day) of the $18^{\circ} \mathrm{C}$ series (' $a$ ' value for $13^{\circ} \mathrm{C}: 64.5 \mathrm{cal} /$ day). In herring-fed series, at $13{ }^{\circ} \mathrm{C}$, the exponent is 0.93 (in cod-fed: 0.61 ); however the ' $a$ ' value $(33.5 \mathrm{cal} / \mathrm{day})$ is only about $50 \%$ of the ' $a$ ' value (64.5 cal/day) obtained for cod-fed dabs.

The analyses of the effects of different food quality and temperature permit two conclusions. (1) Temperatures between $13^{\circ}$ and $18^{\circ} \mathrm{C}$ influence the metabolic level but not the weight exponent. (2) Food quality influences the metabolic level as well as the weight exponent.

\section{Discussion}

The results presented have shown that temperature and food quality modify the feeding rates and the relations between food conversion and body weight in the flat fish Limanda limanda. There exist considerable individual and temporal variations in food intake and food conversion, even when the test individuals are kept under almost identical conditions. In regard to food intake, the range of deviations from mean feeding rates was about $60 \%$ for males and about $40 \%$ for females fed herring meat at $13{ }^{\circ} \mathrm{C}$. In other words, temporal variation in food intake is about $1 \frac{1}{2}$ times greater in males than in females. Among males and females of different body weights, however, the values for the range (coefficient) of deviations did not vary significantly. These values (Table 3) represent the average performance of 4 to 5 individuals; the deviation range might have been even wider, if the test individuals had been fed individually. For want of similar data in previous studies, I have not been able to compare these results. However, several workers have at least suggested pronounced day-to-day fluctuations in feeding rates of fishes (Moorn, 1941; Hunt, 1960; PandTan, $1967 \mathrm{~b}, \mathrm{c})$. Moone has probably been the first author who presented daily feeding records in a comprehensive figure. He reported that his test fishes never attained any constant level of food consumption. However, the few data reported by him do not permit detailed quantitative assessments of the daily variations observed.

For technical reasons, I have not been able to study daily variations in rates and efficiencies of food conversion. But such variations must be assumed in view of the daily variations in food intake; food intake is the most potent factor affecting food conversion (BRown, 1957). Palometmo and Diokte (1966a, b), who reexamined literature data on food intake and conversion, showed that flat fishes (DAwEs, 1930-31; HataNAKA et al., 1956a, b) display considerably greater individual and temporal variations than other fishes. This behaviour is supported by the present study.

Why should dab kept under almost identical environmental conditions show such wide variations in rates of food intake and food conversion? A possible reason may be that, at the population level, dabs spawn over several months; at the individual level, they spawn repeatedly (a few thousand eggs each time). The spawning period of Limanda limanda spreads over a period of 9 months; it begins early in January and lasts until JuIy, or even to the end of September in the middle of the North Sea (EHrenbaum, 1910), Peak spawning extends from March to May, when the surface water temperature rapidly increases from about $3^{\circ} \mathrm{C}$ to about $10^{\circ} \mathrm{C}$, a most rapid change for such a short period. Unlike other flat fishes, spawning in the dab is largely independent of hydrographic conditions (Borr, 1957); for this reason the dab has been considered "propagative eurytherm" (AuRrcH, 1940). AURICH, who investigated the distribution and density of pelagic fish eggs in the North Sea over 12 years, reported that $L$. limanda spawns at water temperatures 
varying from $2^{\circ}-3{ }^{\circ} \mathrm{C}$ to over $16^{\circ} \mathrm{C}$ (optimum $3^{\circ}$ to $\left.7^{\circ} \mathrm{C}\right)$ and in salinities ranging from $28-29 \%$ to $35 \%$. Thus, the freshly spawned eggs of the dab are subjected to a wide variety of salinity-temperature conditions, which further vary from year to year, and from place to place.

KINNE (1962) reported that rates of feeding and food conversion in the euryhaline fish Cyprinodon macularius were consistently higher in individuals hatched from eggs that remained in the spawning salinity, than in offspring from eggs which had been transferred to another salinity level. He suggested that the spawning medium affects the physical properties of the immediate environment of the embryo, thus "imprinting" different functional and structural properties that tend to persist - at least in part throughout the individual's life span. Such "conditioning" by the spawning medium may not only affect metabolic processes (KINNE, 1962), but also morphological aspects (SwEET and KINNE, 1964). Comparable: irreversible, non-genetic changes due to temperature history have been demonstrated in Lebistes reticulatus (Gibson, 1954; Gibson and Hirst, 1955; Tsukuda and Katayama, 1957; Tsukuda, 1960). Tsukuda's valuable contribution demonstrates that the process of temperature acclimation is affected by the thermal history. Though similar investigations are wanting for Limanda limanda, some evidence is available on temperature effects during early development of other flat fishes. The vertebra number is determined at an early developmental stage (gastrula) in Pleuronectes platessa (Dannevig, 1950). Flüchter and Pandian (1968) showed that temperature not only controls the rate of development, but also affects the hatching size, by altering the yolk utilization efficiency, of the sole Solea solea. In the light of such information it may be suggested that the individual variations observed in rates of food intake and conversion in dabs are possibly due to "irreversible nongenetic adaptation" (KINNE, 1962) induced in freshly spawned eggs, subjected to a wide variety of temperature-salinity combinations.

The results obtained on the average rates of food intake and conversion in dabs provide evidence that body weight affects rate and efficiency of metabolism. Intake of food per unit fish weight per unit time decreases with increasing body weight (except for females at $8^{\circ} \mathrm{C}$ ); this trend is also seen in body weightconversion efficiency relationships. An indirect negative correlation between body weight and feeding rate has been shown by previous workers such as KINNE (1960), Menzel (1960) and Pandian (1967 b). Feeding rate apparently decreases at a faster rate than respiratory metabolism, i.e. the increase in energy input (food intake) is not proportionate to the increase in energy output through metabolism. Per gram dab weight increase, food intake increases by a factor of 0.54 at $13^{\circ} \mathrm{C}, 0.57$ at $18^{\circ} \mathrm{C}(0.88$ for dabs fed herring meat at $\left.13{ }^{\circ} \mathrm{C}\right)$; the respective values for metabolic increase are
$0.61,0.58$ (and 0.93). Data published by PANDIAN (1967 b) for 2 tropical fishes fed with prawn ad libitum at $28^{\circ} \mathrm{C}$ demonstrated that food intake increases by a factor of 0.71 in Megalops cyprinoides and 0.76 in Ophiocephalus striatus, while the energy expended on metabolism increases 0.77 and 0.88 , respectively. Decrease in conversion efficiency with increasing body weight is, therefore, not directly due to body weight, but to the reduced feeding rate. Palohermo and DickIx (1966 b) also concluded that body weight affects feeding, but is not a determining factor for conversion efficiencies.

With regard to the differences in feeding rates observed among female and male dab, the following is to be said: My observation that males feed less than the females, differs from the findings of DAwES $(1930-31)$ in plaice Pleuronectes platessa. DAwws fed plaice in their natural habitat, and reported that the maintenance feeding level of male plaice was greater than that of the female in Cowsand (Fngland), and in individuals of less than $80 \mathrm{~g}$ body weight in Lympstone (England). Patohermo and Drokte (1966a), who re-examined DAwEs data, found that the differences reported by DAwEs were not statistically significant. In general, growth rates among males and females differ considerably in flat fishes; such differing growth rates become particularly apparent only at a definite size, which varies from species to species (BoHL, 1957). Differences in growth rate become apparent in $P$. platessa, when it reaches about $20 \mathrm{~cm}$ standard length (about $150 \mathrm{~g}$ body weight) at the beginning of the 4th year of its life, while in Limanda limanda it becomes apparent at $12 \mathrm{~cm}$ standard length (less than $10 \mathrm{~g}$ body weight) at the beginning of the 2nd year. DAwEs used 2 year old plaice of less than $120 \mathrm{~g}$ body weight, in which growth differences due to sex are not yet pronounced, while the dab used $(>10 \mathrm{~g})$ in the present study were already showing marked differences in growth rates of females and males. Therefore, the results obtained for dab, though of the same body weight, are not strictly comparable to those reported for plaice by DAwES.

For a similar reason, my data are not strictly comparable to those reported for the Japanese dab Limanda yokahamae (HATANAKA et al., 1956a). Japanese dab, varying from 68 to $259 \mathrm{~g}$ body weight, were fed at $13.1^{\circ} \mathrm{C}$. Since male and female individuals were kept together in groups, no differences in feeding rates of males and females could be observed. Sexual differences in growth rate become apparent only when $L$. yokahamae attain body weights of about $167 \mathrm{~g}$ at the commencement of their second year of life. Also for similar reasons, my data are not directly comparable to the results reported by HATANAKA et al. (1956b) for the Japanese plaice Kareius bicoloratus.

The feeding responses of dab to temperature permits three interesting conclusions (Fig. 3). 
(1) The temperature optimum for maximum food uptake shifts downward with increasing body weight in both sexes. That the temperature optimum for growth or metabolism is body weight-dependent has only recently been recognized and hence there is scant evidence. Studies on the growth of the desert fish Cyprinodon macularius by KTNNE (1960) offer such evidence. In $C$. macularius the temperature level $30^{\circ} \mathrm{C}$ is optimal for smaller individuals; in larger individuals (older than 22-28 weeks) the temperature optimum shifts gradually downwards to $22^{\circ}-26^{\circ} \mathrm{C}$. From his oxygen consumption studies on Salvelinus fontinalis, JoB (1955) concluded that the smaller individuals were "better off" at higher temperatures $\left(15^{\circ}\right.$ and $\left.20^{\circ} \mathrm{C}\right)$ than at the lower temperature levels $\left(5^{\circ}\right.$ and $\left.10^{\circ} \mathrm{C}\right)$, whereas, for the larger ones, the opposite was true.

(2) Differences in the feeding response of dab due to temperature changes are more pronounced in smaller individuals than in larger ones. The smaller dab either fed and gorged themselves at the higher test temperatures, or completely ceased to feed at the lower temperatures. Data by HATANAKA et al. (1956a) for the Japanese dab Limanda yokahamae show that individuals of about $100 \mathrm{~g}$ body weight consumed about $1 \frac{1}{2}$ times more food at an average ambient temperature of $19.0^{\circ} \mathrm{C}$, than at $8.4^{\circ} \mathrm{C}$, although larger individuals $(200 \mathrm{~g})$ showed almost no difference. The results of MENZEL (1960) on Epinephelus guttatus revealed that the increase in food intake is about $224 \%$ and $190 \%$ higher at $28^{\circ} \mathrm{C}$, than at $19^{\circ} \mathrm{C}$, for individuals of 100 and $600 \mathrm{~g}$ body weight, respectively. Such body weightdependent temperature effects can even be evident in fishes fed during the acclimation period. Feeding rate of Lepomis gibbosus is about 5 times higher in smaller individuals (of about $14 \mathrm{~g}$ ) at $20^{\circ} \mathrm{C}$ than at $10^{\circ} \mathrm{C}$ (this difference is only 3 times in larger individuals of 44 to $81 \mathrm{~g}$; Hathaway, 1927). Wood (1952) and Pandian $(1967 \mathrm{c})$ reported that, in regard to variations in food quality, there are wide differences in the feeding rates of smaller individuals; the magnitude of the differences decreases progressively with increasing body weight. Such weight-related differences have not only been observed in regard to food intake, but also to oxygen uptake. Due to a change in temperature from $5^{\circ}$ to $20^{\circ} \mathrm{C}$, metabolism (non-dependent active) of a $5 \mathrm{~g}$ Salvelinus fontinalis rises 2.8 times (an individual weighing $1,000 \mathrm{~g}$ exhibited an increase of 1.3 times). Thus, smaller individuals are more sensitive and their responses are more pronounced to changes in environmental factors, such as temperature and food quality, than larger individuals.

(3) The "normal temperature" is narrower in dabs of less than $40 \mathrm{~g}\left(13^{\circ}\right.$ to $\left.18^{\circ} \mathrm{C}\right)$ than in larger individuals $\left(3^{\circ}-8^{\circ}\right.$ to $\left.18^{\circ} \mathrm{C}\right)$. Although records of such bodyweight-related differences in "normal temperature" ranges are lacking, there exists a considerable amount of literature concerning temperature requirements for maturation of sexual products, spawning and early development, which differ from the ones at which the animal feeds and actively grows (KINNE, 1963). The dab's gonads ripen during fall, when temperatures rapidly decrease; the optimum temperature for spawning ranges from $3^{\circ}$ to $7^{\circ} \mathrm{C}$ (AURICH, 1940). Dabs weighing more than $40 \mathrm{~g}$ belong to the actively-reproducing group, while those of less than $40 \mathrm{~g}$ are either immature, or their contribution to the egg production of the total population is almost negligible (BoHr, 1957). The wide "normal temperature" range of larger adult individuals may be considered to be a non-genetic adaptation, acquired possibly due to seasonal temperature variations over a period of about 3 to 4 consecutive years.

The optimum temperature for food conversion efficiency lies between $13^{\circ}$ and $18^{\circ} \mathrm{C}$ for immature Limanda limanda, and at $8^{\circ} \mathrm{C}$ for mature individuals of both sexes; the optimum temperature for food conversion efficiency decreases with increasing body weight. Furthermore, taking any one of the 4 different body weight groups into consideration (Fig. 3), optimum temperature for maximum conversion is lower than the temperature at which the dab consumes maximum amounts of food. Exceptions are females over $80 \mathrm{~g}$ body weight, which display maximum rates of feeding and conversion efficiency at the same temperature $\left(8^{\circ} \mathrm{C}\right)$. The results of HATANAKA et al. (1956a) showed that Japanese dab Limanda yokahomae, of less than $100 \mathrm{~g}$, reveal maximum consumption at an ambient temperature of $23.1^{\circ} \mathrm{C}$, but convert most efficiently at a lower temperature of $19.0^{\circ} \mathrm{C}$. KINNE (1960) also reported that Cyprinodon macularius feed maximally at $30^{\circ} \mathrm{C}$, while the optimum temperature for efficient conversion is $20^{\circ} \mathrm{C}$. The fact that food conversion efficiency and food intake have different temperature optima indicates the complex nature of metabolic interactions taking place (PALOHErmo and DiokIE, 1966a). Two aspects may be discussed here. (1) Relative to larger dab, smaller dab appear to have to expend considerably more energy on activity (e.g. swimming, hunting for prey) at a higher temperature $\left(18^{\circ} \mathrm{C}\right)$ than at $13^{\circ} \mathrm{C}$, and hence can convert only a lesser percentage of the food consumed for growth. There is supporting evidence in literature. For example, JoB (1955) found that, at higher temperature levels $\left(20^{\circ} \mathrm{C}\right)$, the non-dependent active metabolic rate of a $5 \mathrm{~g}$ individual of Salvelinus fontinalis was about $352 \%$ higher than its standard rate; this difference amounts to only $276 \%$ for the larger individual $(1,000 \mathrm{~g})$. (2) Although larger dalos (over $40 \mathrm{~g}$ ) of both sexes consume relatively less food at $8^{\circ} \mathrm{C}$ (except females $>80 \mathrm{~g}$ ), they display maximum conversion efficiencies at this temperature. The feeding experiments at $8^{\circ} \mathrm{C}$ were begun in late November, and lasted until early January 1967. The maintenance requirements of these test fishes appear to have been only fractions of the summer maintenance requirements; thereby they have been able to use the food consumed most efficiently. 
Maintenance requirements of the plaice Pleuronectes platessa is significantly reduced during October to December; the magnitude of reduction varied from 50 to $66 \%$ of the summer maintenance requirement (DaWES, 1930-31).

The response of the dabs to changes in food quality were surprising; dabs which received herring meat (series I), consumed and converted considerably more food than the individuals fed cod meat (series II). Consequently, conversion (growth) rates in individuals belonging to series I were 2 to 4 times greater than in those of series II. A similar situation has been observed innatural habitats. For instance, the plaice Pleuronectes platessa were transplanted from the spawning ground (Horn Reef Ground) to other places (e.g. Dogger Bank, North Sea). Due to the availability of a better food quality at Dogger Bank, the transplanted plaice grew 2 to 4 times faster than those left at Horn Reef Ground (Nזkotsky, 1963; p. 207).

The weight exponents for the relationship between food intake and body weight are 0.54 at $13^{\circ} \mathrm{C}$, and 0.57 at $18^{\circ} \mathrm{C}$, for dabs fed with cod meat. The corresponding values for the relationship between metabolic rate and body weight are 0.61 and 0.58 . PaLOHERMo and Dickis (1966a) recalculated the data obtained by DAwES (1930-31) for the plaice Pleuronectes platessa, and Fatanaka et al. (1956a) for the Japanese dab Limanda yokahamae. They reported a weight exponent for the metabolism-body weight relation of 0.62 for plaice and 0.65 for Japanese dab. A remarkable feature is that the weight exponents of all the three flat fishes are significantly lower than the values reported for other fishes investigated. However, it is not possible to arrive at any definite conclusion, as the weight exponent obtained for dab fed with herring meat is 0.93 , and that obtained by DAwES (1930-31) for plaice (which received an intermediate food supply between ad libitum and minimum maintenance feeding) is also 0.93 (PALOhermo and DickTe, 1966a).

The weight exponents displayed only small variations at temperatures ranging from $13^{\circ}$ to $18^{\circ} \mathrm{C}$; however, there was a change in the ' $a$ ' value. The ' $a$ ' value, for instance, for the metabolism-body weight relation at $18{ }^{\circ} \mathrm{C}(78.2 \mathrm{cal} /$ day $)$ is $18 \%$ higher than at $13^{\circ} \mathrm{C}(64.5 \mathrm{cal} / \mathrm{day})$. The fact that temperature influences not the weight exponent but only the metabolic level, has been demonstrated by PaLOHEIMO and DICKIE (1966a), using KINNE's (1960) data on Cyprinodon macularius. Within the range $20^{\circ}$ to $30^{\circ} \mathrm{C}$, C. macularius displays weight exponents of $0.63 \pm 0.10$. The ' $a$ ' value of the slope for $30^{\circ} \mathrm{C}$ was about 3 times higher than the one for $20^{\circ} \mathrm{C}$.

Food quality exerts significant influences not only on the weight exponent, but also on the metabolic level. Limanda limanda fed. with herring meat at $13^{\circ} \mathrm{C}$ display a weight exponent of 0.93 , which is significantly greater than that (0.61) obtained in cod-fed individuals at $13{ }^{\circ} \mathrm{C}$. The ' $a$ ' value of the former is $33.5 \mathrm{cal} / \mathrm{day}$, i.e. only half that of the latter $(64.5 \mathrm{cal} /$ day). As there is no previous work available for comparison, further discussion is not possible. However, the fact that food quality affects not only the weight exponent, but also the metabolic level, calls for further investigation.

\section{Summary}

1. Intake and conversion of food were studied as functions of body weight, sex, temperature and food quality in the flat fish Limanda limanda from the southern North Sea.

2. With increasing body weight, both female and male $L$. limanda consume less food per unit body weight; irrespective of body weight ( 1 to $150 \mathrm{~g}$ ), females consume more food than corresponding males when offered herring meat at $13{ }^{\circ} \mathrm{C}$ (series I); the degree of this difference is body weight-dependent.

3. Temporal and individual variations in daily feeding rates are considerable; deviation from mean feeding rate amounts to about $60 \%$ for males and $40 \%$ for females. The degree of deviation does not vary significantly among females and males of different body weights.

4. Females consume almost the same amount, or less, cod meat than molles, at $13{ }^{\circ} \mathrm{C}$ (series II). Among individuals of series I and II, feeding rates differed somewhat. Herring-fed individuals receive about 1.7 times more energy than those fed cod meat. One gram wet weight of herring and cod meat yields 2001 and 1137 calories, respectively.

5. Smaller Limanda limanda (less than $60 \mathrm{~g}$ ) do not feed at $3{ }^{\circ} \mathrm{C}$, while larger individuals consume about $1 \%$ of their body weight/day. Although large individuals feed normally at $8^{\circ} \mathrm{C}$, small ones (less than $17 \mathrm{~g}$ ) refuse to feed. Females weighing over $80 \mathrm{~g}$ feed at maximum rates at $8^{\circ} \mathrm{C}$. Smaller individuals of both sexes consume maximum amounts of food at $13^{\circ}$ and $18^{\circ} \mathrm{C}$. The optimum temperature for maximum food intake decreases with increasing body weight.

6. Feeding with cod or herring meat for about 30 days results in considerable changes in regard to composition and calorific content in the dab L. limanda. The degree of these changes depends on both temperature and food quality. At $13{ }^{\circ} \mathrm{C}$, herring-fed dabs contain as much as $7.6 \%$ more energy per unit weight than at the beginning of the feeding experiment, the corresponding increases are only $3.6 \%$ at $8{ }^{\circ} \mathrm{C}, 4.5 \%$ at $13{ }^{\circ} \mathrm{C}$ and $2.5 \%$ at $18{ }^{\circ} \mathrm{C}$ for dabs which receive cod meat.

7. Food conversion efficiency values in herring-fed dabs are about $1 \frac{1}{2}$ times higher than those in individuals fed cod meat. In both series I and II, females are more efficient converters than males. In dabs weighing more than $50 \mathrm{~g}$, conversion efficiency decreases in the order $8^{\circ}, 13^{\circ}, 18^{\circ} \mathrm{C}$; for smaller individuals the order of decrease is $13^{\circ}, 18^{\circ}, 8^{\circ} \mathrm{C}$. Thus, optimum 
temperature for maximum conversion efficiency decreases with increasing body weight. In each tested individual, the optimum temperature for maximum conversion efficiency was lower than the temperature at which maximum food intake occurred.

8. Conversion rates are about 2 to 5 times faster in herring-fed dab than in cod-fed ones. Conversion rates decrease in males in the order $13^{\circ}, 8^{\circ}, 18^{\circ} \mathrm{C}$; in females in the order $18^{\circ}, 13^{\circ}, 8^{\circ} \mathrm{C}$; females of more than $80 \mathrm{~g}$ respond exceptionally, they reach maximum conversion rates at $8^{\circ} \mathrm{C}$.

9. The weight exponents obtained for the relationship between body weight and rates of food intake and metabolism of cod-fed dabs at $13^{\circ}$ and $18^{\circ} \mathrm{C}$ amount to about 0.6 ; ' $a$ ' values, or metabolic levels, are about 2 times higher at $18^{\circ} \mathrm{C}$ than at $13^{\circ} \mathrm{C}$. Thus, the temperature affects the metabolic level but not the exponential value.

10. The weight exponents obtained for the body weight relation to rates of food intake and metabolisma of herring-fed dabs at $13^{\circ} \mathrm{C}$ are about 0.9 ; ' $a$ ' values amount to only about one half of those obtained for dab fed on cod meat. Food quality, unlike temperature, alters not only the weight exponents, but also the metabolic level.

Acknowledgements. The work presented was conducted under the guidance of Prof. O. KrNNE (Hamburg) and submitted to the University of Kiel in candidature for the degree of Dr. rer. nat. I am deeply indebted to Prof. KINNE for help and support. It is a pleasure to thank Prof. K. PaMPaPater RaO (Bangalore University, India) for critically going through the manuscript and for valuable suggestions. I am grateful to Herrn J. K. Hotmmane and Frl. A. Rermens (Biologische Anstalt Helgoland) for technical assistance. Thanks are extended to Mrs. Katre Shakuntala and to my wife Shantha Pavolan, who have kindly assisted in preparing figures and manuscript. A fellowship awarded by the DAAD, Bad Godesberg (Germany), is gratefully acknowledged.

\section{Literature cited}

AURICH, $\mathrm{H}$ : Die Verbreitung der pelagischen Fischbrut in der südlichen Nordsee während der Frühjahrsfahrten 19261937. Helgoländer wiss. Meeresunters. 2, 183-225 (1940).

Benanrst., F. W. H. and L. M. Dickie: Metabolism and biological production in fish. Int. biol. Symposium, Reading, 215-242 (1966).

BoнL, H.: Die Biologie der Kliesche (Limanda limanda L.) in der Nordsee. Ber. dt. wiss. Kommn. Meeresforsch. 15, 1-57 (1857).

BRETT, J. R.: Some principles in the thermal requirements of fishes. Q. Rev. Biol. 31, $75-87$ (1956).

Brown, M. E.: Experimental studies on growth. In: The physiology of fishes, Vol. 1, pp 361-400. Ed. by M. E. Brown. New York: Academic Press 1957.

BULLOCK, T. H.: Compensation for temperature in the metabolism and activity of poikilotherms. Biol. Rev. 30, 311$342(1955)$.

BüCKMans, A.: Vorläufige Mitteilung über Fütterungs- und Wachstumsversuche mit Schollen im Aquarium. Kurze Mitt. fischbiol. Abt. Max-Planck-Inst. Meeresbiol. Wilhelmsh. 1, 8-21 (1952).

DANNEVIG, A : The influence of environment on number of vertebrae in plaice. FiskDir. Skr. (Havundersøk.) 9, 9 (1950).
- and S. HANSEN: Faktorer av betydning for fiskeeggenes og Fiskeyngelens oppvekst. FiskDir. Skr. (Havundersøk.) 10, $5-36$ (1952).

Dawes, B.: The absorption of fats and lipoids in the plaice (P. platessa L.). J. mar. biol. Ass. U K. 17, 75-102 (1930).

- Growth and maintenance in the plaice ( $P$. platessa L.). Pts 1 \& 2. J. mar. biol. Ass. U.K. 17, 103-174; 877-947 $(1930-31)$

Ehrenbaum, E.: Eier und Larven von Pleuronectiden der Nordsee und benachbarter Gewässer. Rapp. P.-v. Réun. Cons. perm. int. Explor. Mer 12 (C 3), 1-32 (1910).

FLÜCHTER, J. and T. J. PANDIAN: Rate and efficiency of yolk utilization in developing eggs of the sole Solea solea. Helgoländer wiss. Meeresunters. 18, 53-60 (1968).

FRY, F. E. J.: Effeets of environment on animal activity. Univ. Toronto Stud. biol. Ser. ( = Publs Ont. Fish. Res. Lab. 68) $55,1-63(1947)$.

- The aquatic respiration in fish. In: The physiology of fishes, Vol. 1, pp 1-63. Ed. by M. E. Brown. New York: Academic Press 1957.

GERKTNG, S. D.: The protein metabolism of the sunfishes of different ages. Physiol. Zoöl. 25, 358-372 (1952).

- The food turnover of a bluegill population. Ecology $\mathbf{8 5}$, $490-498$ (1954).

- Influence of rate of feeding on body composition and protein metabolism of bluegill sunfish. Physiol. Zoöl. 28, 267-282 (1955).

Groson, M. B.: Upper lethal temperature relation of the guppy Lebistes reticulatus. Can. J. Zool. 32, 393-407 (1954).

- and B. HuRsT: The effect of salinity and temperature on the pre-adult growth of guppies. Copeia 241-243 (1955).

Hataraka, M, M. KosakA and Y. Sato: Growth and food consumption in plaice. 1. Limanda yok chamae (GüNTHER) Tohoku J. agric. Res. 7, 151-162 (1956a).

- - - Growth and food consumption in plaice. 2. Kareius bicoloratus (BASILESKY). Tohoku J. agric. Res. 7, 163-174 $(4956 \mathrm{~b})$.

-, K. Sakino, T. Takahashi and T. IchmuURa: Growth and food consumption in young mackerel Pneumatophorus japanicus (HoutTuXN). Tohoku J. agric. Res. 7, 351-368 (1957).

HATHAWAX, E. S.: The relation of temperature to the quantity of food consumed by fishes. Ecology 13, 423-434 (1927).

HUNT, B. P.: Digestion rate and food consumption of Florida gar, warmouth, and largemouth bass. Trans. Am. Fish. Soc. 99, 206-210 (1960).

IVLEV, V S.: Balance of energy in carps. Zool. Zh. 18, 303-318 (1939).

- The biological productivity of waters. [Transl. from Russ.]. Adv. contemp. Biol. ( = Russ. Rev. Biol. = Usp. sovrem. Biol.) 19, 98-120 (1945).

JAKOVLEV, V.: Vorläufige Mitteilung über die Untersuchung des Wassergehalts bei Schollen und Klieschen. Mitt. Inst. Fischbiol. Univ. Hamburg 7, 23-26 (1957).

JoB, S. V.: The oxygen consumption of Salvelinus fontinalis. Univ. Toronto Stud. biol. Ser. ( = Publ. Ont. Fish. Res. Lab. 73) 61, 1-39 (1955).

KINNE, O.: Growth, food intake and food conversion in a euryplastic fish exposed to different temperatures and salinities. Physiol. Zoöl. \$32, 288-317 (1960).

- Irreversible nongenetic adaptation. Comp. Biochem. Physiol. 5, 265-282 (1962).

- The effect of temperature and salinity on marine and brackish water animals. 1. Temperature. Oceanogr. mar. Biol. A. Rev. 1, 301-340 (1963).

- Non-genetic adaptation to temperature and salinity. Helgoländer wiss. Meeresunters. 9, 433- $\mathbf{4 5 8}$ (1964).

KÜ®L, H.: Nahrungsuntersuchungen an einigen Fischen im Elbe-Mündungsgebiet. Ber. dt. wiss. Kommn. Meeresforsch. $16,90-104(1961)$.

LuNDB̈ck, J.: Fischkunde für Jedermann, Vol. 1, 231 pp. Neumünster: Plambeck 1955 (Praxis der Fischwirtschaft). 
MaynaRD, A. L. and K. J. LoosuI: Animal nutrition, 5th ed., $533 \mathrm{pp}$. New York: Mc-Graw Hill 1962.

MenzeL, D. W.: Utilization of algae for growth by the angel fish. J. Cons. perm. int. Explor. Mer 24, 308-313 (1959).

- Utilization of food by a Bermuda reef fish Epinephelus guttatus. J, Cons. perm. int. Explor. Mer 25, 216-222 (1960).

MOORE, W. G.: Studies on the feeding habits of fishes. Ecology $22,91-96$ (1941).

NIKoLSKY, G. V.: The ecology of fishes, [Transl. from Russ.]. 352 pp. New York: Academic Press 1963.

PATNE, R. T.: Endothermy in bomb calorimetry. Limnol. Oceanogr. 11, 126-129 (1966).

PaLohetmo, J. E. and L. M. Dickte: Food and growth of fishes. 2. Effects of food and temperature on the relation between metabolism and body weight. J. Fish. Res. Bd Can. 23, $869-908$ (1966a).

- - Food and growth of fishes. 3. Relations among food, body weight and growth efficiency. J. Fish. Res. Bd Can. 23, 1209-1248 (1966b).

Pandian, T. J.: Food intake, absorption and conversion in the fish Ophiocephalus strialus. Helgoländer wiss. Meeresunters. 15, 637-647 (1967a).

- Intake, digestion, absorption and conversion of food in the fishes Megalops cyprinoides and Ophiocephalus striatus. Mar. Biol. 1, 16-32 (1967b).

- Transformation of food in the fish Megalops cyprinoides. 1. Influence of quality of food. Mar. Biol. 1, 60-64 (1967c).

- Transformation of food in the fish Megalops cyprinoides. 2. Influence of quantity of food. Mar. Biol. 1, 107-109 $(1967 \mathrm{~d})$.

RÜHMER, S.: Fische und Natztiere des Meeres, 256 pp. Ebenhausen/München: Rühmer 1954.

SLMPSON, A. C.: Some observations on the mortality of fish and the distribution of plankton in the southern North Sea during the cold winter 1946-1947. J. Cons. perm. int. Explor. Mer 19, 150-177 (1953).
Stydermany, C. J.: Diseases in marine fishes. Adv. mar. Biol. 4, 1-89 (1966).

Sмгтн, H. W.: The metabolism of the lung fish. 2. Effects of feeding on meat in the metabolic rate. J. cell. comp. Physiol. $6,335-349(1935)$.

SwEET, J. G. and O. KINNE: The effects of various temperaturesalinity combinations on the body form of newly hatched Cyprinodon macularius (Teleostei). Helgoländer wiss. Meeresunters. 11, $49-69$ (1964).

TsukdDA, H.: Temperature adaptation in fishes. 3. Temperature tolerance of the guppy Lebistes reticulatus in relation to the rearing temperature before and after birth. Biol. J. Nara Women's Univ. 10, 11-14 (1960).

- and T. KaTAY AMA: Temperature adaptation in fishes. 1. The influence of rearing temperature on the temperature tolerance, growth rate and body form. Seiro-Seitai 7, 113-122 (1957).

VINOGRADOV, A. P.: The elementary composition of marine organism. [Transl. from Russ.]. 647 pp. New Haven: Yale University Press 1953. (Mem. Sears Fdn mar. Res. 2).

WildIAMs, W. E.: Food consumption and growth rates for large and small mouth bass in the laboratory aquaria. Trans. Am. Fish. Soc. 88, 125-127 (1959).

WIMPENNY, R. S.: The plaice, 145 pp. London: Arnold \& Co. 1953.

WINBERA, G. G.: Rate of metabolism and food requirements of fishes, 253 pp. Minsk: Belorusskogo Nauchnye Trudy Belorusskogo Gosudarstvennogo Universiteta imeni V.I. Lenina 1956. (Transl. Fish. Res. Bd Can. No 362).

Woon, E. M.: Method of protein studies with trout with applications of four selected diets. Ph. D. thesis, Ithaca, N.Y., Cornell Univ. (1952).

Author's address: Dr. T. J. Pandian Zoology Department Bangalore University Bangalore 1, India

Date of final manuscript acceptance: October 28, 1969.Communicated by N. K. PanIKkaR, New Delhi, and O. KINNe, Hamburg 